Review

\title{
Transformation products of pharmaceuticals in surface waters and wastewater formed during photolysis and advanced oxidation processes - Degradation, elucidation of byproducts and assessment of their biological potency
}

\author{
D. Fatta-Kassinos ${ }^{\text {a,*, }}$, M.I. Vasquez ${ }^{\text {a }}$, K. Kümmerer ${ }^{\text {b }}$ \\ ${ }^{a}$ Gaia - Laboratory of Environmental Engineering, Department of Civil and Environmental Engineering, University of Cyprus, 75 Kallipoleos, 1678 Nicosia, Cyprus \\ ${ }^{\mathrm{b}}$ Material Resources, Institute of Environmental Chemistry, Leuphana University, Lüneburg Scharnhorststraße 1.C13, 21335 Lüneburg, Germany
}

\section{A R T I C L E I N F O}

\section{Article history:}

Received 1 April 2011

Received in revised form 19 June 2011

Accepted 20 June 2011

Available online 10 August 2011

\section{Keywords:}

Pharmaceutical

Transformation product

Photolysis

Advanced oxidation process

Antibiotic activity

(Eco)toxicity

\begin{abstract}
A B S T R A C T
The significance of transformation products of pharmaceuticals resulting from the parent compounds during natural and technical photolytic processes and advanced oxidation processes has only recently started to attract the interest of the scientific community. Even though relevant studies have now started to produce important knowledge, still many gaps exist that hinder the in-depth and broad understanding of the extent of the potential problems stemming from the presence of such compounds in the environment and the applicability of such techniques for wastewater and potable water treatment. The great diversity of pharmaceutical compounds, the variety of processes and conditions applied by the various research groups active in the field, and the endless list of potential biological endpoints that could potentially be explored, coupled with the limitations related to the analytical capabilities presently available, are some of the crucial parameters that characterize this challenging research direction. This review paper tries to highlight some of the most relevant studies performed so far and to summarize the parameters that prevent scientists from reaching comprehensive conclusions in relation to the formation, fate, and effects of transformation products of pharmaceutical compounds during photo-driven and advanced oxidation processes.
\end{abstract}

(c) 2011 Elsevier Ltd. All rights reserved.

\section{Contents}

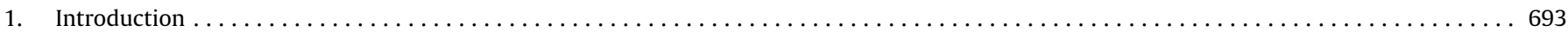

2. Photolysis: degradation rates, elucidation of byproducts and assessment of their biological potency. . . . . . . . . . . . . . . 694

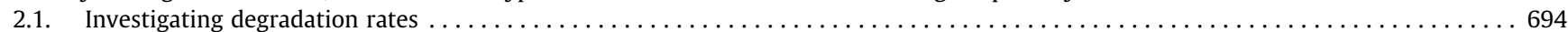

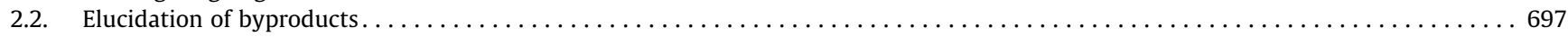

2.3. Assessment of the biological potency of byproducts formed during photolysis . . . . . . . . . . . . . . . . . . . . .

3. Identification of pharmaceuticals' transformation products during advanced oxidation processes and assessment of their biological potency 702

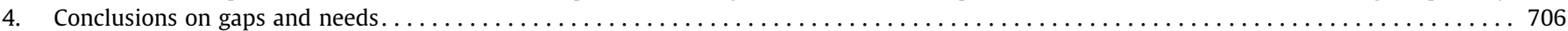

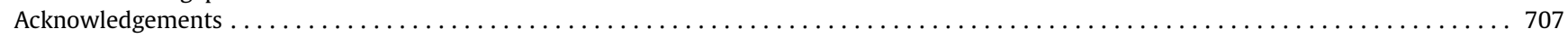

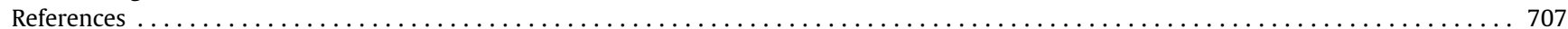

\section{Introduction}

All types of urban wastewater discharge and reuse practices, including irrigation of landscape and agricultural areas, groundwater replenishment, discharge into inland surface waters and sea, cause the release of organic xenobiotic substances into the environment. Fresh surface water bodies are most often used both

\footnotetext{
* Corresponding author.

E-mail address: dfatta@ucy.ac.cy (D. Fatta-Kassinos).
}

for receiving treated effluents but also for providing water for the production of drinking water. Therefore, many of these organic compounds including pharmaceuticals, which constitute one of the most diverse chemical classes of compounds (Heberer, 2002; Kümmerer, 2008, 2009), find their way into the urban water cycle.

Biological processes can induce the formation of only a limited degree of transformation because of the biopersistence of many organic compounds. The same holds true often for the number transformation products resulting from incomplete biodegradation. The biochemical reactions are governed by specific pathways 
and enzymes while photoprocesses and some other non-biotic reactions are less "guided". Especially if radicals are involved, which are avoided in biochemical pathways, myriads of reaction products will result because these reactions are not specific.

Abiotic environmental factors on the other hand, can make a significant contribution to the transformation of such substances in the environment. Abiotic factors are chemical and physical factors such as temperature, soil composition, amount, intensity and wavelength of sunlight (here latitude is of importance with regards to temperature), salinity, and $\mathrm{pH}$. Biotic factors are the other living parts of the ecosystem with which an organism may interact; the organisms present and their diversity in number, type and function. Normally only bacteria and fungi degrade organic compounds - in the best case they mineralize the compounds to inorganic salts, carbon dioxide and water. That is the only case where, in principle, no further effects resulting from the products of degradation are of concern.

The number of studies that report photo degradation rates for pharmaceutical compounds outweigh by far those that identify photoproducts and photo degradation pathways. Product identification is one of the most difficult aspects of these studies, and a potential compromise is the preliminary identification by modern analytical methods such as LC-MS/MS or MS (e.g. by ion-trap) or Orbitrap and/or addressing the photoproducts' mixture biological activity without identifying them, i.e. to combine photochemical studies with biological assays. However, in these cases even though the studies reach conclusions in respect to the exhibition or not of toxicity or any other biological activity of the photoproducts it remains unclear which compounds are these in respect to structural elucidation.

Further to the abiotic and biotic processes that can induce a great variety of transformation products (TPs) for the pharmaceutical compounds in the environment, the same processes can have the same effect on these compounds during the treatment processes applied at the sewage and drinking water treatment plants. Hence, biologically and chemically transformed products may result during treatment. It is important to underline the fact that knowledge on the biodegradation products of pharmaceuticals, i.e. TPs formed during biological wastewater treatment is currently only little (Zwiener et al., 2002; Miao and Metcalfe, 2003; Quintana et al., 2005). Studies focusing on this topic should be undertaken so that the possible hazards related to the biotransformation products released in the environment can be also assessed.

Further to the aforementioned, during the application of advanced oxidation processes (AOPs), the main concern, relates to the formation of various products as a consequence of the nonselectivity of HO radicals that may trigger complex reaction pathways. AOPs can be broadly defined as aqueous phase oxidation methods based on the intermediacy of highly reactive species such as (primarily but not exclusively) hydroxyl radicals in the mechanisms leading to the destruction of the target pollutant. During treatment, the disappearance of the original drug may therefore not imply that the treatment is efficient and hence further measurements such as some conventional global parameters, including TOC (total organic carbon), COD (chemical oxygen demand), DOC (dissolved organic carbon), adsorbable organic halogen (AOX), and the presences of chromophores and flourophores via UV-Vis and fluorescence measurements can be used to assess the processes which based on what said before, are not capable to provide solid conclusions on the overall efficiency of the process and the safe use or reuse potential of the treated flow. These products may preserve the mode of action of the parent compound or even be biologically more active (Rosal et al., 2009; Sirtori et al., 2010). They may retain the properties of the parent compound like for instance antibiotic activity. Furthermore, in the cases where AOPs are combined with the biological treatment, the TPs formed could be more bioresistant and/or induce adverse effects on the activity of microbial population present in the activated sludge system.

The important environmental issue that arises from the increasing presence of pharmaceutical compounds and other micro-pollutants in the environment is the fact that the biological, chemical (e.g. by ozone or other oxidizing agents) or phototransformation of these drugs occurring following exposure to sunlight or during sewage treatment has only recently started to attract the scientific interest. Knowledge has only now started to be developed with regard to the identification of photoproducts and at a lower degree on the biological potency of these individual products. As Boreen et al. already discussed in their review paper in 2003, the structural variability within pharmaceutical compounds requires that their photoreactivity be assessed on a case-by-case basis and this nowadays still holds true for all micro-pollutants.

For a complete risk assessment study on the TPs of pharmaceuticals formed during photolytic natural processes and treatment of water and wastewater, determination of their toxicity and ecotoxicity is fundamental and a prerequisite for comprehensive protection of the environment. In published studies about TPs of pharmaceuticals, toxicity has been generally taken as the overall toxicity of the solution (i.e. mixture of intermediates and possibly parent compound) by the Microtox test. The Microtox test measures the decrease in bioluminescence of the marine bacterium $V$. fischeri, as a result of inhibiting bacterial luciferase upon contact with toxic substances. This test is frequently used in the environmental studies, since it is simple, fast, sensitive and reproducible (Radjenović et al., 2009a). However, the test uses a marine organism and since the interest for water and wastewater use and reuse practices are mainly in the fresh and terrestrial environment more suitable bioassays should be applied too. In addition, Microtox test lacks sensitivity to low concentrations. Further to the above, the real significance of this test in terms of (eco)toxicity is not known. Therefore it can only be a very first indication without providing information on potential gene toxicity, neurotoxicity, etc.

This review paper tries to roughly compile the knowledge that has been gathered during the last decade on the identification of TPs formed during the application of natural photolytic and advanced oxidation processes; driven or not by light. Moreover, it tries to present the knowledge available on the potential biological effects that these products may cause. Relevant knowledge gaps along with the need for reporting more uniform data with regard to the various experimental conditions applied are discussed and highlighted, the objective being to have comparable data and information relevant to real environmental conditions. For this purpose wherever possible, uniform data is provided for each of the studies presented herein so as to be able to extract solid conclusions with regard to the varying experimental conditions applied.

\section{Photolysis: degradation rates, elucidation of byproducts and assessment of their biological potency}

\subsection{Investigating degradation rates}

The efficacy of the photochemical transformation process in surface water is dependent on many environmental factors such as the depth of the water column, turbidity, geographic latitude, season, weather and shadow (e.g. provided by trees and bushes) and also on all the factors mentioned in the introductory part affecting abiotic processes. Photo degradation can be either direct or indirect. In direct photolysis, a molecule absorbs solar radiation, i.e. energy, which leads to a break-up of the molecule, while indirect photolysis involves naturally occurring molecules such as nitrates which generate strong reactive species e.g. singlet oxygen $\left({ }^{1} \mathrm{O}_{2}\right)$, hydroxyl radicals (HO') or alkyl peroxyl radicals ('OOR) 
and "aqueous" electrons (i.e. an electron released during ionization of a water molecule by water and surrounded by water molecules oriented so that the electron cannot escape) under solar radiation. Absorption of actinic radiation (i.e. electromagnetic radiation that can produce photochemical reactions) by nitrate and dissolved organic matter leads to the production of most of these species, but the carbonate radical is generated from the reaction of hydroxyl with carbonate/bicarbonate ions, which can act as HO- scavengers, by slowing down or even preventing degradation. Another indirect photolysis reaction is photosensitization, where energy absorbed by a light-absorbing species, such as colored dissolved organic matter in its triplet state, is transferred to an organic species at ground state inducing its excitation so that it can be involved in photolytic reactions. Humic acids can reduce the rate of photo transformation by absorbing light and acting as an inner filter; thus hindering the transfer of energy to other compounds such as pharmaceuticals (e.g. Prabhakaran et al., 2009). On the other hand, some studies (e.g. Peuravuori and Pihlaja, 2009) have revealed the essential function of natural chromophores in dissolved organic material as principal photosensitizer toward indirect phototransformation of pharmaceuticals in natural conditions under available low-energy as discussed further below.

The hydroxyl radical, HO; has a non-selective and highly electrophilic nature and it is therefore the most reactive of the aforementioned intermediates. Second-order reaction rate constants for this oxidant with numerous organic compounds approach diffusion-limited values $\left(10^{7}-10^{10} \mathrm{M}^{-1} \mathrm{~s}^{-1}\right)$ (Buxton et al., 1988). Although it is reported to be present at $10^{-14}-10^{-18} \mathrm{M}$ in surface waters (Russi et al., 1982; Brezonik and Fulkerson-Brekken, 1998), this reactive moiety can significantly contribute to reactions of photo transformation like for example $\mathrm{H}$-abstraction and addition to double bonds, thereby enabling degradation products resulting from direct and indirect photolysis to be distinguished (Lam and Mabury, 2005).

There are several indications that photochemical degradation is one of the most important processes with regard to the determination of the environmental fate of pharmaceuticals in the environment. Many of these compounds have aromatic rings, heteroatoms, and other functional chromophore groups that can either absorb solar radiation or react with photogenerated transient species in natural waters (e.g. reactive oxygen species and photo excited natural organic matter-NOM). Further, some of these compounds also contain structural moieties, such as phenol, nitro, and napthoxyl groups, which are similar to those found in pesticides that have been found to undergo photodegradation (Boreen et al., 2003).

Because many of the pharmaceutical pollutants in surface waters have already escaped intact the intensive biodegradation environment of activated sludge treatment, photochemistry may be expected to play a much more important role than biodegradation, in natural waters under solar irradiation. Some compounds may also evade photochemical degradation through sorption to suspended particles (in general sorption often results in an activation of the molecule i.e. increased access and rate of photodegradation).

The studies discussed below have been carried out with the objective of gathering information on the kinetics and efficiency of direct and/or indirect photolysis to degrade parent compounds in natural water bodies. A few examples on photodegradation studies (without elucidation of byproducts) are summarized in $\mathrm{Ta}-$ ble 1 while some other examples are discussed in more detail below, the reason being to exemplify the many variations with regard to the methodology followed and conditions applied, hindering the extraction of concrete and unequivocal results.

For instance, the photodegradation of two fluoroquinolone veterinary antibiotics, difloxacin and sarafloxacin has been explored by Prabhakaran et al. (2009) using millipore and river water. The study was performed to evaluate the influence of $\mathrm{pH}$, inorganics, humic substances, and other additives. A photoreactor equipped with xenon lamp, temperature sensor and water-cooling circuit was used as the source for artificial sunlight. Quartz containers were used for the irradiation of sample solutions maintained at a distance of $17 \mathrm{~cm}$ from the lamp. The experiments were performed at $35 \pm 1^{\circ} \mathrm{C}$. The lamp intensity was $500 \mathrm{~W} \mathrm{~m}^{-2}$ with a spectral wavelength ranging between 290 and $800 \mathrm{~nm}$. By using potassium ferrioxalate actinometric method, the photon flow was found to $2.98 \times 10^{15}$ photons s $^{-1}$. The drugs followed first-order degradation kinetics in matrix free aqueous medium with a rate constant $k$ value of 0.82 and $0.26 \mathrm{~h}^{-1}$ for difloxacin and sarafloxacin respectively. Studies performed at various $\mathrm{pH}$ revealed that the photolysis rates dropped sharply at $\mathrm{pH}>7$ for difloxacin, while sarafloxacin dissipated faster with increasing $\mathrm{pH}$. Humic substances acted as light barriers by attenuating the light intensity, to retard the drug degradation process. However, rapid drug dissipation was observed in the presence of additives like acetone, hydrogen peroxide, and phosphates, while inorganics such as fluoride, nitrate, and sulfate did not influence the drug photodegradation. Studies on the photolysis of difloxacin and sarafloxacin in river water revealed that both drugs degraded rapidly under conditions that were relevant to natural systems, following direct photolysis mechanism. It was observed that sarafloxacin was the primary photoproduct of difloxacin and showed relatively a higher persistence than difloxacin (Scheme 1).

Another example refers to the natural sunlight photolysis experiments that were performed with a solution of $5 \mu \mathrm{M}$ of the compound in milli-Q water by Werner et al. (2005). The direct photolysis solar quantum yield of mefenamic acid was observed to be $1.5 \pm 0.3 \times 10^{-4}$. Solutions were adjusted to $\mathrm{pH} 8.0$ and sun irradiated $\left(45^{\circ}\right.$ latitude; average $\left.T=18 \pm 2{ }^{\circ} \mathrm{C}\right)$. Further photosensitization and quenching experiments were performed indoors using a merrygo-round reactor at a radius of $10 \mathrm{~cm}$ from a borosilicate-filtered $450 \mathrm{~W}$ medium-pressure Hg-vapor lamp. The temperature was kept near $25^{\circ} \mathrm{C}$ via the use of a cooling fan and a water-cooled borosilicate well which enclosed the lamp. Significant photosensitization was observed in solutions of river water. Quenching, sparging and light-filtering experiments suggested a direct reaction of mefenamic acid with excited triplet-state dissolved organic matter as the major photosensitization process. The compound was observed to undergo direct photolysis with a half-life of $33 \mathrm{~h}$ under direct noon sunlight, which would correspond to a minimum aquatic direct photolysis half-life of $66 \mathrm{~h}$ at the water surface under these conditions, after correcting for the lens effect of the test tube. Due to its low quantum yield, the loss of mefenamic acid in sunlit natural waters was found to depend on both direct and indirect photodegradation processes.

The kinetics of simulated low-energy daylight UVA-Vis $(315<\lambda<800 \mathrm{~nm})$ and powerful combined ultraviolet B and A (UVB-UVA, $280<\lambda<400 \mathrm{~nm}$ ) induced direct and indirect phototransformations of ibuprofen, metoprolol, carbamazepine, and warfarin (with initial concentration of each drug $404 \mu \mathrm{g} \mathrm{L}{ }^{-1}$ ), in dilute solutions of pure laboratory and natural humic lake waters (pH 5.8) in a study by Peuravuori and Pihlaja (2009). The results confirmed the essential function of natural chromophores in dissolved organic material as principal photosensitizer toward indirect phototransformation of pharmaceuticals in natural conditions under available low-energy UVA-Vis and slight UVB radiations. The results confirmed that the compounds are able to undergo a direct photolysis if their absorbance spectra overlap the spectral range of the available radiation but only if the radiation is strong enough. The action of nitrate anions as photosensitizers in the applied conditions proved to be of little importance.

From the studies described above and from those presented in Table 1 , it is apparent that many of the parameters involved in 
Table 1

Examples of photodegradation studies with the objective of determining degradation rates.

\begin{tabular}{|c|c|c|c|c|c|}
\hline $\begin{array}{l}\text { Compounds } \\
\text { Initial concentration } \\
\text { Matrix }\end{array}$ & Light source & $\begin{array}{l}\text { Technical experimental } \\
\text { details }\end{array}$ & Radiation data & Findings & Reference \\
\hline $\begin{array}{l}\text { Norfloxacin } \\
\text { doxycycline } \\
\text { mefenamic acid }\end{array}$ & $\begin{array}{l}15 \mathrm{~W} \text { low pressure } \\
\text { mercury vapor } \\
\text { lamp using UV-C } \\
\text { radiation }\end{array}$ & $\begin{array}{l}\text { In the presence and absence of } \\
\text { hydrogen peroxide or sodium } \\
\text { monopersulfate }\end{array}$ & $\begin{array}{l}\text { Quantum yields: }(1.1- \\
4.5) \times 10^{-3} \text { mol einstein }^{-1}\end{array}$ & $\begin{array}{l}\text { The inorganic peroxides considerably enhanced the contaminants } \\
\text { conversion }\end{array}$ & $\begin{array}{l}\text { Rivas et al. } \\
(2010)\end{array}$ \\
\hline \multirow{2}{*}{$\begin{array}{l}10.0 \times 10^{-5} \mathrm{M} \text { each } \\
\text { of the compounds } \\
\text { in pure water }\end{array}$} & & $T$ constant at $20^{\circ} \mathrm{C}$ & Actinometry, with hydrogen peroxide $\rightarrow$ & $\begin{array}{l}\text { No appreciable mineralization could be obtained indicating the } \\
\text { formation of photoproducts }\end{array}$ & \\
\hline & & $\begin{array}{l}\text { Initial } \mathrm{pH} \text { : } \\
5.5 \text { for norfloxacin } \\
3.5 \text { for doxycycline } \\
10.0 \text { for mefenamic acid }\end{array}$ & $\begin{array}{l}\text { - Incident radiation intensity per volume } \\
\mathrm{Io}=3.3 \times 10^{-6} \mathrm{EL}^{-1} \mathrm{~s}^{-1} \\
- \text { Radiation pathlength in the reactor } \\
L=3 \mathrm{~cm}\end{array}$ & $\begin{array}{l}\text { The rate constant between hydroxyl radicals and norfloxacin was } \\
\left(k>1 \times 10^{9} \mathrm{M}^{-1} \mathrm{~s}^{-1}\right) \text {, doxycycline }\left(k>1.5 \times 10^{9} \mathrm{M}^{-1} \mathrm{~s}^{-1}\right) \text { and } \\
\text { mefenamic acid }\left(k>11.0 \times 10^{9} \mathrm{M}^{-1} \mathrm{~s}^{-1}\right)\end{array}$ & \\
\hline $\begin{array}{l}\text { Difloxacin } \\
\text { sarafloxacin }\end{array}$ & $\begin{array}{l}\text { Suntest } \\
\text { CPS + photoreactor }\end{array}$ & $T: 35 \pm 1^{\circ} \mathrm{C}$ & lamp intensity was $500 \mathrm{~W} \mathrm{~m}^{-2}$ & $\begin{array}{l}\text { First-order degradation kinetics with a rate constant } k \text { value of } 0.82 \\
\text { and } 0.26 \mathrm{~h}^{-1} \text { for difloxacin and sarafloxacin, respectively }\end{array}$ & \multirow[t]{3}{*}{$\begin{array}{l}\text { Prabhakaran } \\
\text { et al. (2009) }\end{array}$} \\
\hline \multirow[t]{2}{*}{$\begin{array}{l}10 \mu \mathrm{gL}^{-1} \text { in millipore } \\
\text { and river water }\end{array}$} & \multirow[t]{2}{*}{$\begin{array}{l}\text { Equipped with } \\
\text { xenon lamp }\end{array}$} & & \multirow{2}{*}{$\begin{array}{l}\text { Actinometry with } \\
\text { ferrioxalate } \rightarrow \text { photon } \\
\text { flow } 2.98 \times 10^{15} \text { photons s }{ }^{-1}\end{array}$} & $\begin{array}{l}\text { The photolysis rates dropped sharply at } \mathrm{pH}>7 \text { for difloxacin, while } \\
\text { sarafloxacin dissipated faster with increasing } \mathrm{pH}\end{array}$ & \\
\hline & & & & $\begin{array}{l}\text { Humic substances acted as light barriers by attenuating the light } \\
\text { intensity, to retard the drug degradation process }\end{array}$ & \\
\hline Oseltamivir & \multirow[t]{2}{*}{ Direct sunlight } & \multirow{2}{*}{$\begin{array}{l}\text { Under sterile and non-sterile } \\
\text { conditions simulating shallow water } \\
\text { processes at the latitude of } \\
\text { approximately } 52^{\circ} \mathrm{N}\end{array}$} & \multirow{2}{*}{$\begin{array}{l}\text { Solar radiation data }\left(\mathrm{J} \mathrm{m}^{-2} \mathrm{~s}^{-1}\right) \text { in the } \\
\text { range of } 400-1100 \mathrm{~nm} \text { were continuously } \\
\text { recorded every } 5 \mathrm{~min} \text { with a Li-200SA } \\
\text { pyranometer sensor }\end{array}$} & $\begin{array}{l}\text { Using a river water solution under non-sterile conditions a half-life } \\
\text { time of } 17.8 \mathrm{~d} \text { was observed }\end{array}$ & \multirow{2}{*}{$\begin{array}{l}\text { Bartels and } \\
\text { von Tümpling } \\
\text { (2008) }\end{array}$} \\
\hline $\begin{array}{l}50 \mu \mathrm{g} \mathrm{L}^{-1} \text { in milli- } \mathrm{Q} \text { and } \\
\text { river water }\end{array}$ & & & & $\begin{array}{l}\text { Direct photolysis was found to play no or only a negligible role for } \\
\text { the decomposition of oseltamivir. Its degradation according to the } \\
\text { study seemed to occur as a combination of microbial metabolism } \\
\text { and indirect photolysis whereas particles }>0.7 \mu \mathrm{m} \text { may have an } \\
\text { impact on these processes }\end{array}$ & \\
\hline $\begin{array}{l}\text { Acetaminophen } \\
\text { atenolol } \\
\text { carbamazepine } \\
\text { ibuprofen } \\
\text { ifenprodil } \\
\text { indomethacin } \\
\text { mefenamic acid } \\
\text { propranolold } \\
100 \mathrm{mg} \mathrm{L}^{-1} \text { in pure water }\end{array}$ & Direct sunlight & $\begin{array}{l}\text { The test tubes were exposed to } \\
\text { sunlight between 08:00 and 18:00 } \\
\text { on the rooftop of a building (approx. } \\
34^{\circ} \text { north latitude) }\end{array}$ & $\begin{array}{l}\text { p-Nitroacetophenone-pyridine solutions } \\
\text { were used as actinometers }\end{array}$ & $\begin{array}{l}\text { Propranolol, indomethacin, and ifenprodild were easily } \\
\text { photodegraded (half-life }<24 \mathrm{~h} \text { ), whereas the other five } \\
\text { pharmaceuticals were stable against sunlight }\end{array}$ & $\begin{array}{l}\text { Yamamoto } \\
\text { et al. (2009) }\end{array}$ \\
\hline
\end{tabular}


<smiles>CN1CCN(c2cc3c(cc2F)c(=O)c(C(=O)O)cn3-c2ccc(F)cc2)CC1</smiles><smiles>O=C(O)c1cn(-c2ccc(F)cc2)c2cc(N3CCNCC3)c(F)cc2c1=O</smiles>

Scheme 1. Difloxacin (left) and sarafloxacin (right) chemical structures.

such investigations, differ substantially. Fig. 1 presents the most important parameters that vary during the available photodegradation studies. It is also important to highlight the fact that these parameters significant for solid comparison and extraction of insight are not always provided in the studies' descriptions. Such parameters include amongst others the irradiation set-ups, the characteristics of the light source, the water matrix used, the initial concentration of the micro-pollutants and its environmental relevance, the application of direct and indirect photolysis and the $\mathrm{pH}$ of the solutions. When using ultrapure matrices then it is still not known whether the pharmaceutical compounds and all other xenobiotic organics of course will behave in the same way when present in natural fresh waters. If natural waters are used standardization is not possible. Therefore, it would be of interest to have studies using both types of matrices. Furthermore, all studies are performed with individual compounds and not with mixtures, as is the actual situation in nature, or during wastewater and surface water treatment. Added to this, it is also possible that combined processes including photolysis, biodegradation and absorption on the suspended particles may be responsible for the possible elimination or partial transformation of the compounds. To gain better insight into the significance of the individual parameters it is desirable to have more systematic studies and not just a trial investigating the photodegradation of a compound under conditions chosen according to the available laboratory techniques and equipment.

\subsection{Elucidation of byproducts}

The same variety of conditions is most frequently applied for the studies aiming at identifying TPs during photolysis (Table 2). The main difficulties when studying the pharmaceuticals' (photo)chemical behavior in environmental matrices are linked to the very low environmentally relevant concentrations (ng $\mathrm{L}^{-1}$ to $\mu \mathrm{g} \mathrm{L}^{-1}$ ) which can generate problems in relation to the analytical sensitivity. Moreover, the complexity of aqueous matrices i.e. wastewater, can affect the degradation kinetics of the pollutants.

According to Albini and Fasani (1998) it is possible to indicate some molecular features that are likely to make a molecule liable to photodecomposition, even if it is difficult to predict the exact photochemical behavior of a specific molecule. This is due to the fact that competition between the chemical reaction(s) and physical decay to the ground state depends in a complex way on the structure (and on conditions). The following chemical functions are expected to introduce photoreactivity (besides the presence of unsaturated bonds that can absorb radiation):

- The carbonyl group. This behaves as an electrophilic radical in the $n \pi^{*}$ excited state. Typical reactions are reduction via intermolecular hydrogen abstraction and fragmentation either via $\alpha$ cleavage ("Norrish Type I") or via intramolecular $\gamma$-hydrogen abstraction followed by $\mathrm{C}_{\alpha}-\mathrm{C}_{\beta}$ cleavage ("Norrish Type II").

- The nitroaromatic group, also behaving as a radical, and undergoing intermolecular hydrogen abstraction or rearrangement to a nitrite ester.

- The N-oxide function. This rearranges easily to an oxaziridine and the final products often result from further reaction of this intermediate.

- The $\mathrm{C}=\mathrm{C}$ double bond, liable to $\mathrm{E} / \mathrm{Z}$ isomerisation as well as to oxidation.

- The aryl chloride, liable to homolytic and/or to heterolytic dechlorination.

- Products containing a weak $\mathrm{C}-\mathrm{H}$ bond (i.e. so called $\mathrm{CH}$-acidic compounds), e.g. at a benzylic position or a to an amine nitrogen. These compounds often undergo photoinduced fragmentations via hydrogen transfer or electron-proton transfer.

\footnotetext{
Photoreactor

-shape, material, type, geometry, cooling system, reaction radiation pathlengths, in case of beakers their distance from the lamp

Light

-type of lamp (Xe, Hg, Ra), low/medium/high pressure, power, spectral wavelength, photon flow, intensity, irradiance, spectral irradiance, natural light: characteristics, hours during day light, light dose, fluence rate, use of optical filters

Matrix

-ultrapure water, deionized water, distilled water, surface water (river, lake, lagoon), sewage effluent, synthetic surface water, synthetic sewage effluent, $\mathrm{pH}$, temperature, presence or absence of inorganic/humic sensitizers or radical scavengers

Compound

-initial concentration, quantum yield of the compound

Other

-actinometric method

-information on whether hydrolysis - thermolysis - striping were checked

-information on replicates of experimental runs / statistical elaboration of results
}

Fig. 1. Parameters provided/not provided during experimental studies and when provided vary thus hindering concrete comparisons of findings. 
Table 2

Examples of photodegradation studies with elucidation of byproducts.

\begin{tabular}{|c|c|c|c|c|c|c|}
\hline $\begin{array}{l}\text { Compounds } \\
\text { Initial concentration } \\
\text { Matrix }\end{array}$ & Light source & $\begin{array}{l}\text { Technical } \\
\text { experimental } \\
\text { details }\end{array}$ & Radiation data & Byproducts & Findings & Reference \\
\hline \multirow{3}{*}{$\begin{array}{l}\text { Acebutolol, alprenolol, atenolol, } \\
\text { metoprolol, nadolol, propranolol, } \\
\text { pindolol, sotalol, timolol, } \\
\text { bisoprolol } \\
10 \mu \mathrm{g} \mathrm{L}^{-1}, 10 \mathrm{mg} \mathrm{L}^{-1}\end{array}$} & \multirow{4}{*}{$\begin{array}{l}\text { High-pressure vapor } \\
\text { mercury lamp (250- } \\
600 \mathrm{~nm})\end{array}$} & \multirow{4}{*}{$\begin{array}{l}\text { Pyrex glass immersion } \\
\text { photochemical reactor, } \\
\text { cutting out } \\
\text { wavelengths shorter } \\
\text { than } 280 \mathrm{~nm}\end{array}$} & \multirow[t]{4}{*}{-} & \multirow{4}{*}{$\begin{array}{l}\text { For acebutolol, } \\
\text { propranolol, } \\
\text { pindolol, timolol }\end{array}$} & $\begin{array}{l}\text { The concentration does not influence the type of } \\
\text { photoproducts }\end{array}$ & \multirow[t]{4}{*}{$\begin{array}{l}\text { Piram et al. } \\
\text { (2008) }\end{array}$} \\
\hline & & & & & The same photoproducts appeared in both matrices & \\
\hline & & & & & $\begin{array}{l}\text { Hydroxyl radical addition was identified as an important } \\
\text { degradation pathway for ß-blockers }\end{array}$ & \\
\hline $\begin{array}{l}\text { Pure water and sewage } \\
\text { treatment plant effluent }\end{array}$ & & & & & $\begin{array}{l}\text { Several positional isomers corresponding to the addition } \\
\text { of one, two or three hydroxyl groups to the parent } \\
\text { molecule have been identified }\end{array}$ & \\
\hline \multirow{2}{*}{$\begin{array}{l}\text { Metoclopramide } \\
10 \mu g \mathrm{~L}^{-1}-10 \mathrm{mg} \mathrm{L}^{-1} \\
\text { Millipore aqueous solutions }\end{array}$} & \multirow{2}{*}{$\begin{array}{l}\text { Rayonet photochemical } \\
\text { reactor equipped with four } \\
\text { UV fluorescent lamps }\end{array}$} & \multirow[t]{2}{*}{$\begin{array}{l}\text { Under argon } \\
\text { atmosphere }\end{array}$} & \multirow[t]{2}{*}{-} & \multirow[t]{2}{*}{ Yes } & $\begin{array}{l}\text { The structures of } 18 \text { photolysis products were } \\
\text { tentatively identified }\end{array}$ & \multirow{2}{*}{$\begin{array}{l}\text { Maquille and } \\
\text { Habib Jiwanb } \\
\text { (2009) }\end{array}$} \\
\hline & & & & & $\begin{array}{l}\text { The main degradation mechanism was scission of the } \\
\text { chlorine that could be followed by di- and trimerization } \\
\text { of the resulting products since dimeric and trimeric } \\
\text { products were observed }\end{array}$ & \\
\hline \multirow{4}{*}{$\begin{array}{l}\text { Flupentixol } \\
0.5 \mathrm{mg} \mathrm{mL}^{-1} \\
\text { Deionized water }\end{array}$} & \multirow{4}{*}{$\begin{array}{l}\text { Photochemical reactor } \\
\text { equipped with four UV } \\
\text { fluorescent lamps }\end{array}$} & \multirow[t]{4}{*}{$\begin{array}{l}\text { Under room } \\
\text { temperature }\end{array}$} & \multirow[t]{4}{*}{-} & \multirow[t]{4}{*}{ Yes } & $\begin{array}{l}\text { The major photodegradation pathway occurred through } \\
\text { hydroxyl addition on the double bond }\end{array}$ & \multirow[t]{4}{*}{$\begin{array}{l}\text { Maquille et al } \\
\text { (2010) }\end{array}$} \\
\hline & & & & & $\begin{array}{l}\text { For the majority of the photoproducts, the thioxan-thene } \\
\text { ring remained intact although oxidation into } \\
\text { thioxanthone was observed for three minor products }\end{array}$ & \\
\hline & & & & & $\begin{array}{l}\text { a total of nine photoproducts were detected after } \\
\text { irradiation of the drug }\end{array}$ & \\
\hline & & & & & $\begin{array}{l}\text { The main photoproduct was generated following the } \\
\text { addition of a hydroxyl group on the double bond } \\
\text { adjacent to the thioxanthene ring }\end{array}$ & \\
\hline \multirow{3}{*}{$\begin{array}{l}\text { Atorvastatin, } \\
\text { carbamazepine, } \\
\text { levofloxacin, } \\
\text { sulfamethoxazole } \\
10 \mu \mathrm{M} \\
\text { Surface water }\end{array}$} & \multirow{3}{*}{$\begin{array}{l}\text { Suntest CPS Photosimulator } \\
\text { equipped with a Xe lamp as } \\
\text { the UV radiation source and } \\
\text { glass filters restricting the } \\
\text { transmission of wavelengths } \\
\text { below } 290 \mathrm{~nm}\end{array}$} & \multirow[t]{3}{*}{-} & \multirow[t]{3}{*}{ Lamp intensity $765 \mathrm{~W} \mathrm{~m}^{-2}$} & \multirow[t]{3}{*}{ Yes } & $\begin{array}{l}\text { All compounds were found to be susceptible to direct } \\
\text { and indirect photodegradation }\end{array}$ & \multirow{3}{*}{$\begin{array}{l}\text { Lam and } \\
\text { Mabury } \\
\text { (2005) }\end{array}$} \\
\hline & & & & & $\begin{array}{l}\text { The longest half-time determined was that of } \\
\text { carbamazepine: } 115 \pm 4 \mathrm{~h} \text {. Like sulfamethoxazole, half- } \\
\text { lives of levofloxacin in the presence of surface water } \\
\text { components were generally longer than its half-life in } \\
\text { pure water suggesting that direct photochemical } \\
\text { reactions are more important in limiting the persistence } \\
\text { of this compound }\end{array}$ & \\
\hline & & & & & $\begin{array}{l}\text { Atorvastatin degraded at a faster rate in all surface water } \\
\text { solutions compared to pure water, suggesting that } \\
\text { indirect photochemical reactions significantly } \\
\text { contribute to its photolytic fate in sunlit surface waters }\end{array}$ & \\
\hline
\end{tabular}




\section{Propranolol}

$10 \mu \mathrm{g} \mathrm{L}-1$

Natural surface wate

\section{Diclofenac}

$45.5 \mathrm{mg} \mathrm{L}^{-1}$

Demineralised water and freshwater water

\section{Hydrochlorothiazide}

$100 \mu \mathrm{M}$

treatment plant water reconstructed standard

Distilled water and sewage
Both with a solar simulator -

$(150 \mathrm{~W})$ and by direct

sunlight
Filters to remove wavelengths $<290 \mathrm{~nm}$

Light intensity: $41 \mathrm{~W} \mathrm{~m}^{-2}$
3 L beakers (Pyrex) - $\quad$ - Yes

(1)

es

Bezafibrate, gemfibrozil,

fenofibrate and fenofibric acid

$24 \mu \mathrm{M}$

Distilled water and sewage
$150 \mathrm{~W}$ solar simulator equipped with a Xenon lamp
Carbamazepine, ibuprofen and ketoprofen $10-40 \mathrm{mg} \mathrm{L}^{-1}$

Pure water

Filtered seawater River water
Suntest CPS equipped with a Xenon lamp $1500 \mathrm{~B} \mathrm{NrB}$ for elimination of infrared radiation above $750 \mathrm{~nm}$

The temperature was stable at $45^{\circ} \mathrm{C}$
Sunlight radiation was daily For ketoprofen time dependant from 0 to $1000 \mathrm{~W} \mathrm{~m}^{-2}$ and with day average of $270 \mathrm{~W} \mathrm{~m}^{-2}$
Major direct photolysis products were identified from propranolol that led to a proposed reaction pathway, involving ring oxidation, rearrangement, and

deoxygenation

The overall results demonstrated that with fast direct photolysis half-lives, propranolol is unlikely to be persistent in natural waters

Propranolol products $m / z 292$ showed more than five structural isomers in two clusters, possibly due to photo-induced ring opening and rearrangement

In river waters, four major groups of transformation products were found from metoprolol with $m / z 226, m / z$ $254, \mathrm{~m} / \mathrm{z} 284$ and $\mathrm{m} / \mathrm{z} 300$

The 13 photoproducts identified demonstrated that photolysis of diclofenac occurs by two main routes. On is the consequence of the initial photocyclisation of diclofenac into carbazole derivatives. The other route goes through the initial decarboxilation of diclofenac and further oxidation of the alkyl-chain, which are typical photolytic process reactions

The main photoproduct identified was 8-chloro-9Hcarbazole-1yl-acetic acid

The photoproducts obtained were 4-amino-6-chloro1,3-benzenedisulfonamide, 6-hydroxy-3,4-dihydro-2H1,2,4-benzothiadazine-7-sulfonamido-1,1-dioxide and 4-amino-6-hydroxy-1,3-benzenedisulfonamide

The same photoproducts were obtained for the two aqueous matrices suggesting a unique pathway for the compound in water, where the main processes are the photohydrolysis of the thiadazine ring and the photosubstitution of the chlorine with the hydroxyl group

The pathways involve the aryloxy moiety as key reactive Cermola et al. site and well-stabilized radicals (or radical ions) as intermediates

Formation of phenols occurs by a homolytic cleavage of the aryloxy bond followed by hydrogen abstraction from the aryloxy bond followed by hydrogen abstracti
the solvent, for bezafibrate and require aerobic the solvent,
conditions

Formation of ethers can be explained by a ionic photodecarboxylation process of the dissociated acids to aryloxy-substituted carbanions which are protonated by water. Photodecarboxylation is also the first event followed by a [1,2]-Wittig rearrangement

The photodegradation pathway described in this study involved a decarboxylation $\left(-\mathrm{CO}_{2}\right)(2)$ that can react with $\mathrm{O}_{2}$ and after that with radical $\mathrm{HO}$ to produce compound (3). Then demethylation and subsequent cleavage of the two rings may occur, to get more labile structures that are easily removed by biotic or abiotic pathways

Brigante et al.
(2005)
Cermola et al.
(2005)


- Sulfides, alkenes, polyenes and phenols. These are highly reactive with singlet oxygen, formed through photosensitisation from the relatively harmless ground state oxygen.

Such functions are present in a very large fraction, if not the majority, of commonly used pharmaceuticals leading to the formation of photoproducts, however, often the chromophores present are isolated and therefore only short wavelengths are absorbed which are not present in sun light and the often applied mercury medium pressure lamps. Therefore, the molecules are often not accessible to photodegradation.

Novel mass-spectrometry analyzers (e.g. quadrupole time-offlight enabling accurate-mass measurements, linear ion trap and hybrid quadrupole linear ion trap offering high-sensitivity multiple MS experiments) are powerful tools for identifying the so-called known unknownś, i.e. TPs of pharmaceuticals. Although these highly sensitive, selective methods afford reliable results in the process of qualitative analysis, gas chromatography (GC)- and liquid chromatography (LC)- hyphenated techniques are frequently engaged as complementary analytical tools (e.g., LC-nuclear magnetic resonance spectroscopy, LC-ultraviolet detection, LC-infrared spectroscopy, GC-MS and LC-MS) (Radjenović et al., 2009a,b). Here we should also mention that even with such sophisticated equipment, only the compounds that can be extracted during the samples treatment and those that are sufficiently ionized in the ion source under the selected conditions can be detected. No other conclusions can be drawn on potentially other compounds present in the samples.

Starting out from having a structure similar to that of the parent compound, TPs are not completely unknowns. Their structures are elucidated by comparing the mass spectra of the analyte and its TPs, considering possible molecular changes relative to the parent compound and using possible transformation pathways. In any way though, the absence of analytical reference standards hinders the accurate and unequivocal quantification of degradation products of pharmaceuticals. In this respect, MS combined with UV or fluorescence detectors in liquid chromatography can provide additional results that allow for a better interpretation (e.g. presence or absence of certain structural elements).

The studies presented herein have advantages on the theoretical investigation of the elucidation of byproducts (Table 2). However, there is the question on how these studies can substantially contribute to the understanding of the overall fate of pharmaceuticals in field conditions where sunlight has a wide wavelength range and the compounds 'cocktail' effects in aqueous environments are much more complex with numerous organic and inorganic chemicals, including nutrients and suspended solids. Furthermore, as already mentioned, meteorological and hydrological parameters, such as light intensity, light penetration due to possible water turbidity and mixing, but also plants and trees shadow, latitude, adsorption of compounds on suspended matter, etc. can influence the phototransformation kinetics and its efficiency and efficacy in water. Whilst light intensity can be corrected in relation to field conditions in different regions and seasons, light spectra of the solar simulator have to be almost identical to sunlight with polychromatic wavelength range. Here it is important to note that many of the studies dealing with elucidation fail to report radiation data. Furthermore, standard environmental fate tests are separated into either biotic or abiotic degradation; however, in river waters these processes occur simultaneously. The relative significance of depletion mechanisms in surface waters has not been fully understood yet; consequently there are difficulties in interpreting test results relative to what actually happens in the natural environment.

\subsection{Assessment of the biological potency of byproducts formed during photolysis}

Another important question is whether TPs retain some of the parent compounds' biological activity and potency or even have higher potency than the initial compound. Only few studies have dealt with this topic and some examples are discussed below.

An example is difloxacin photolysis, which was performed in water under stimulated natural sunlight conditions, by Kusari et al. (2009) with initial concentrations of $10 \mu \mathrm{g} \mathrm{mL}^{-1}$. Difloxacin was found to primarily degrade to sarafloxacin (see also Fig. 1). On prolonged photodegradation, seven photoproducts were elucidated along with the transformation pathway. Their residual antibacterial activities were studied against a group of pathogenic strains. Both compounds revealed potency against both Grampositive and negative bacteria. TPs also exhibited varying degrees of efficacies against the tested bacteria depending on the time duration of the photolysis demonstrating substantial activity even after $5 \mathrm{~h}$ of photolysis. Even without isolating the individual photoproducts, their impact on the aquatic environment could be assessed. It appeared that the anti-bacterial action of difloxacin and its TPs in the water samples was most pronounced on the clinically important Gram-negative bacterium K. pneumoniae, followed by the Grampositive S. aureus. A general trend of decrease in the anti-bacterial activity of difloxacin was seen over time as it degraded to form its photoproducts. However, an interesting observation was noted after $3 \mathrm{~h}$ of irradiation onwards. The concentration of difloxacin fell below the minimum inhibitory for S. aureus and Escherichia coli between the 3rd and the 4th hour of irradiation and for K. pneumoniae after $8 \mathrm{~h}$. Nevertheless, the antibacterial activity of the irradiated water samples remained notable till the 5 th hour both for $S$. aureus, and for $E$. coli. These anti-bacterial efficacies were most probably due to the single or collective effects of the difloxacin photoproducts: sarafloxacin and photoproducts A-G. However, since $C$ and F were instantaneously degraded to $\mathrm{E}$ and $\mathrm{G}$, respectively, the anti-bacterial efficacies of $C$ and $F$ could be considered negligible. Furthermore, since there was no activity of the irradiated samples against $K$. pneumoniae after $8 \mathrm{~h}$, two inferences could be drawn: firstly, the antimicrobial efficacy of the irradiated samples from $6 \mathrm{~h}$ onwards was contributed primarily by the photoproducts D, E, and G, since sarafloxacin, A, and B diminished below the detection limits after $6 \mathrm{~h}$; secondly, the collective antimicrobial potential of D, E, and G was similar to that of the parent difloxacin. Since the minimum inhibitory concentration of difloxacin against $P$. aeruginosa was the highest of all, it might be conjectured that the anti-bacterial potential in the photoproducts of difloxacin at the available concentrations against it were also negligible.

On the same issue, Sunderland et al. (2001) used the parallel-line bioassay to investigate discrepancies in the zone of inhibition size in conjunction with HPLC analysis for fluoroquinolones photoproducts. The concentration of residual parent fluoroquinolone in each irradiated sample was measured by HPLC and a non-irradiated control solution was prepared at the same concentration. These were compared by parallel-line bioassays using E. coli, Enterobacter cloacae and Klebsiella oxytoca. With ofloxacin and levofloxacin, the zone size for the control solution was significantly less than that of the irradiated solutions, with $>15 \%$ photodegradation in at least two of the indicator organisms, indicating that the photodegradation products possess antimicrobial activity. No difference was seen with ciprofloxacin at any level of photodegradation with any of the indicator organisms, nor with moxifloxacin at $30 \%$ and $54 \%$ photodegradation. A significant difference was observed with $E$. cloacae only, at $83 \%$ photodegradation. These findings suggested that this approach to testing partially photodegradated compounds could identify the presence of microbiologically active products. Such products were most clearly demonstrable in those solutions that 
had undergone $>70 \%$ degradation, but were not always detected by all three indicator strains tested. Therefore, testing a single substantially degradated solution against a panel of organisms is probably the best way to screen for such activity.

The photoproduct biodegradability and toxicity against environmental bacteria for ciprofloxacin was studied also by Vasconcelos et al. (2009) at pH 9, representative for hospitals wastewater and at initial concentration of $100 \mu \mathrm{g} \mathrm{L}^{-1}$, similar to that found in hospitals wastewater. Five TPs were identified as probable products of photo-defluorination, - decarboxylation and loss of the piperazine moiety. These photoproducts were not biodegradable in the Closed Bottle test - OECD 301D. However they did not affect $V$. fischeri in the applied concentrations (a modified method based on ISO/CD 11348, 1994 and the Lumistox LCK 482 was used).

The photolysis behavior of tetracycline (TC, $C_{0}=10-40 \mathrm{mg} \mathrm{L}^{-1}$ ) and toxicity of its degradation products were investigated by Jiao et al. (2008). Two main intermediates with $\mathrm{m} / \mathrm{z}$ of 398 and 413.9 were generated. The naphthol ring of TC remained intact during photolysis. The toxicity of the photolysis compounds was evaluated using $V$. fischeri, and the results revealed that the toxicity increased with irradiation, indicative of a higher adversity risk of the degradation products of TC on bacteria upon photolysis.

The direct photolysis of propranolol and metronidazole was studied by Dantas et al. (2010). For this purpose, 50 and $100 \mathrm{mg} \mathrm{L}^{-1}$ aqueous solutions of the compounds were irradiated by two different UV sources: a $U_{254}$ germicidal lamp and a $U V_{365}$ black light lamp (maximum wavelength is shown). Propranolol direct UVC photolysis produced byproducts with less toxic character while metronidazole irradiation promoted a slight increase of toxicity through the application of Allium test.

The phytotoxicity of diclofenac exposed to natural sunlight was evaluated using synchronized cultures of the unicellular chlorophyte Scenedesmus vacuolatus by Schmitt-Jansen et al. (2007). Inhibition of algal reproduction of the initial diclofenac solution was in the $\mathrm{mg} \mathrm{L}^{-1}$ range indicating no specific toxicity of diclofenac towards S. vacuolatus. Fast degradation of diclofenac was observed with half-lives between 3.3 and $6.4 \mathrm{~h}$ during the first and the third day of exposure, respectively. Phytotoxicity increased after $3.5 \mathrm{~h}$ of exposure of diclofenac to sunlight and showed a maximum of sixfold toxicity after $53 \mathrm{~h}$ of exposure to sunlight. Several phototransformation products were found during the experiment. The time courses of the relative concentration of three transformation products significantly correlated with enhanced phyto-toxicity during the experiment. This indicates a high toxicity potential of photo-transformation products of diclofenac at concentration levels that may come close to environmental concentrations of residual diclofenac after degradation (through the incomplete removal at the treatment plants). The algal reproduction test, applied in this study using synchronized cells, covers a whole life cycle of the organisms and thus integrates over several potential effect sites. The mode-of-action of diclofenac and its transformation products in algae remains unclear at present. The fact that the probably more toxic photo transformation product M-5.58 is less lipophilic than diclofenac indicates that it cannot purely unspecifically act as a narcotic. This is a quite interesting issue that relates to the analogy of biological action between the parent compound and its TPs; a topic, which needs further investigation. Diclofenac was originally designed to inhibit the cyclooxygenase enzyme(s) in humans. Sanz et al. (1998) identified a pathogen-induced oxygenase in tobacco plants that showed significant homology with the cyclooxygenase from animals, also referred to as prostaglandin endoperoxidase synthase, the main target of diclofenac in human cells. An enhanced toxicity of diclofenac after photosensitisation to human erythrocytes was reported by Moore et al. (1990). Whether the oxylipin-based defense system in plants may be a probable target of diclofenac photoproducts remains rather speculative; how- ever, analogies with animal and plant defense systems, based on oxylipins in plants and prostaglandins in animals, respectively, are under discussion (Schmitt-Jansen et al., 2007).

Schulze et al. (2010) identified and subsequently confirmed 2[2-(chlorophenyl)amino]benzaldehyde (CPAB) as a transformation product of diclofenac, with enhanced toxicity using effect-directed analysis. For the phyto-toxicity assessment, a cell reproduction test using unicellular synchronized cultures of the green algae $S$. vacuolatus was used. The $\mathrm{EC}_{50}$ of $\mathrm{CPAB}\left(4.8 \mathrm{mg} \mathrm{L}^{-1}\right)$ was a factor of 10 lower than that for diclofenac $\left(48.1 \mathrm{mg} \mathrm{L}^{-1}\right)$, attributed to the higher hydrophobicity of CPAB ( $\left.\log K_{\mathrm{ow}}=3.62\right)$ compared with diclofenac $\left(\log D_{\text {ow }}=2.04\right)$ at $\mathrm{pH} 7.0$.

The phototransformation of naproxen in aqueous medium has been investigated by DellaGreca et al. (2004). Irradiation of the drug in distilled water induced the formation of six TPs. Three of them were dimeric photoproducts isolated for the first time. The toxicity of the photoproducts and the parent drug has been assayed on $D$. magna and $V$. fischeri. Some photoproducts were more toxic than naproxen.

The photochemical transformation of sulfamethoxazole was investigated in different water matrices: distilled water, distilled water + nitrate (10 and $20 \mathrm{mg} \mathrm{L}^{-1}$ ) and seawater to evaluate its persistence, toxicity and degradation pathway by Trovó et al. (2009b). Acute toxicity of irradiated solutions (using solar simulator) was monitored by $V$. fischeri and $D$. magna bioassays in distilled water. Differences in the degradation rates were observed between distilled water and seawater, being slower in seawater. The cleavage of the sulfonamide bond and the photoisomerization by rearrangement of the isoxazole ring represent the main pathways, at the time that generate the most abundant and persistent intermediates. The acute toxicity of sulfamethoxazole solution varied according to test organisms. D. magna was the most sensitive showing an increase from $60 \%$ to $100 \%$ immobilization after $30 \mathrm{~h}$ of irradiation when depletion of sulfamethoxazole was achieved, thus indicating the higher toxicity of the TPs generated.

In a study performed by Isidori et al. (2006) a solution of furosemide $(0.6 \mathrm{mM})$ in distilled water was irradiated at room temperature for $36 \mathrm{~h}$ by a $150 \mathrm{~W}$ solar simulator. The photoproduct of furosemide in water was identified as dimer 2 on the basis of its spectroscopic features. Bioassays were performed on bacteria, algae, rotifers and microcrustaceans to assess acute and chronic toxicity, while the SOS Chromotest and the Ames test were utilized to detect the genotoxic potential of the investigated compounds. The results showed that acute toxicity was in the order of $\mathrm{mg} \mathrm{L}^{-1}$ for the crustaceans and absent for bacteria and rotifers. Chronic exposure to these compounds caused inhibition of growth population on the consumers, while the algae did not seem to be affected. A mutagenic potential was found for the photoproduct compared to the parent compound. The risk calculated for furosemide suggested its harmlessness on the aquatic compartment. Results from this study demonstrate that both acute and chronic exposure to furosemide and its byproduct do not cause a toxic risk at the order of magnitude of concentrations studied. On the other hand, the harmfulness of the bioactive agent investigated cannot be excluded if the DNA damage found for its derivative is considered. To date, however, no further information on the occurrence of this photoproduct in the environment is available.

The photochemical behavior of three relevant metabolites of the analgesic and antipyretic drug dipyrone, 4-methylaminoantipyrine (4-MAA), 4-formylaminoantipyrine (4-FAA) and 4-acetylaminoantipyrine (4-AAA) was evaluated by Gómez et al. (2008), under simulated solar irradiation. For 4-MAA, different aqueous solutions (synthetic seawater, freshwater and Milli-Q water) as well as different operational conditions were compared. According to the experimental results, 4-MAA resulted to be an easily degraded molecule by direct photolysis, with half-life times ranging 
from 0.12 to $0.58 \mathrm{~h}$, depending on the irradiation conditions. Faster degradation was observed in synthetic waters, suggesting that the photolysis was influenced by the salt composition of the waters. However, no effect on the degradation rate was observed by the presence of natural photosensitizers (dissolved organic matter, nitrate ions). 4-FAA and 4-AAA showed slower photodegradation kinetics, with $t_{1 / 2}$ of 24 and $28 \mathrm{~h}$, respectively. A study of photoproduct identification allowed proposing a tentative photodegradation pathway for 4-MAA and the identification of persistent byproducts in all the cases. The application of an acute toxicity test (D. magna) showed an increase in toxicity during the photolytic process, a consequence of the formation of toxic TPs.

From the studies presented above it is clear that the studies dealing with this interesting issue are increasing. However, there is a serious inconsistency concerning the methodology followed and the experimental conditions applied which cannot contribute to the extraction of general results. A variety of bioassays, species and endpoints are used, while substances along with their concentrations vary. Furthermore, the aqueous matrices (including also the use of photosensitizers, scavengers, etc.) are also different among the various studies and it is apparent that only sparse data for some pharmaceuticals and under very specific conditions are currently available.

\section{Identification of pharmaceuticals' transformation products during advanced oxidation processes and assessment of their biological potency}

In various studies the breakdown pathways and the production of intermediates depend on the type of treatment, even though the processes are driven by the same reactive species, which are mainly hydroxyl radicals. The breakdown pathway is of course related to the characteristics of the specific compound under study but typically, according to Kosjek and Heath (2008), the breakdown involves hydroxylation of the aromatic ring by an electrophilic attack from $\mathrm{HO}$ radicals, cleavage of $\mathrm{C}-\mathrm{O}, \mathrm{C}-\mathrm{N}$ or $\mathrm{S}-\mathrm{N}$ bond and cleavage on $\alpha$-position from the aromatic moiety and ring opening. Furthermore, according to the same study, comparison of the byproducts determined by LC-MS and GC-MS, yields distinctly different compounds, and that implies a need to combine both separation methods in order to obtain a comprehensive view of pharmaceutical transformations.

Table 3 presents recent studies applying advanced oxidation processes for the degradation of various pharmaceutical compounds. Important details are provided on the light source, and other relevant characteristics applied for each of the processes. Whether or not identification of TPs and/or assessment of biological effects of the treated solution carried out is presented.

For example, the phototransformation of clarithromycin and roxithromycin, two human-used macrolides (MLs) was investigated in surface waters in the presence of $\mathrm{Fe}(\mathrm{III})$ by Vione et al. (2009). Initial concentrations were $1.34 \times 10^{-6} \mathrm{M}$ using river water. The experiments were carried out with a $0.5 \mathrm{~L}$ cylindrical immersion-type photo-reactor equipped with a water-cooled, medium-pressure mercury lamp. Photolysis kinetic data suggested that degradation in water would occur via the direct photolysis of the Fe(III)-MLs complexes. Hydroxyl radicals, singlet oxygen and other photooxidants generated from nitrate ions and from excited chromophores present in humic acids appeared to have only a very limited impact on the overall degradation of MLs under the adopted UV-Vis irradiation conditions. A photolysis model applied to the $\mathrm{Fe}(\mathrm{III})$-clarithromycin complex in river water showed that a half-life of $40 \mathrm{~d}$ was predicted under clear-sky irradiation. Three major products were formed mainly implying changes in the structure of the aglycone.
In a study performed by Radjenović et al. (2009b), the technical feasibility and performance of photocatalytic degradation of atenolol has been studied in pilot-plant scale. Compound Parabolic solar Collectors under natural illumination by heterogeneous photocatalysis with $\mathrm{TiO}_{2}$ and homogeneous photocatalysis by photo-Fenton were investigated with two different matrices: distilled water and synthetic municipal wastewater treatment plant effluent adopted from OECD guidelines with TOC $20 \mathrm{mg} \mathrm{L}^{-1}$. The initial concentrations of the pharmaceuticals studied were $10 \mathrm{mg} \mathrm{L}^{-1}$ whereas the concentrations of the catalysts employed were $200 \mathrm{mg} \mathrm{L}^{-1}$ of $\mathrm{TiO}_{2}$ and $5 \mathrm{mg} \mathrm{L}^{-1}$ of iron. Total disappearance of the parent compounds and substantial mineralization were attained in all experiments. Furthermore, kinetic parameters, release of heteroatoms and formation of carboxylic acids were identified. The main intermediate products of photocatalytic degradation of atelonol have been structurally elucidated by tandem mass spectrometry experiments performed at quadrupole-time of flight mass analyzer coupled to ultra-performance liquid chromatograph. Six transformation products were characterized, formed by consecutive attacks of hydroxyl radicals in concomitance with the disappearance of the primary compound.

Méndez-Arriaga et al. (2010) examined the degradation of ibuprofen by photo-Fenton reaction using a solar artificial irradiation. Non-photocatalytic experiments (complex formation, photolysis and $\mathrm{UV} / \mathrm{Vis}-\mathrm{H}_{2} \mathrm{O}_{2}$ oxidation) were executed to evaluate the isolated effects and additional differentiated degradation pathways of ibuprofen. The solar photolysis cleavage of $\mathrm{H}_{2} \mathrm{O}_{2}$ generates hydroxylated-ibuprofen byproducts without mineralization. Fenton reaction, however promotes hydroxylation with a $10 \%$ in form of a mineralization. In contrast, photo-Fenton promotes the decarboxylation of ibuprofen and its total depletion is observed. In absence of $\mathrm{H}_{2} \mathrm{O}_{2}$ a decrease of ibuprofen was observed in the $\mathrm{Fe}(\mathrm{II})$ / UV-Vis process due to the complex formation between iron and the ibuprofen -carboxylic moiety. The degradation pathway was described as an interconnected and successive principal decarboxylation and hydroxylation steps. Total organic carbon depletion of $40 \%$ was observed in photo-Fenton degradation. The iron-ibuprofen binding was the key-point of the decarboxylation pathway. Both decarboxylation and hydroxylation mechanisms, as individual or parallel process were found to be responsible for ibuprofen removal in both Fenton and photo-Fenton systems.

The great variety of possible treatments and conditions (including matrices, treatment reactions, initial concentrations, experimental scale, etc.) that can be applied along with the numerous pharmaceutical substances that exist in commerce demonstrate clearly the many possible TPs that may be formed in urban wastewater treatment plants. The studies discussed below investigated besides TPs, their antibacterial activity (Table 3). Therefore, in order to avoid future problems type of treatments should be selected that result in fast and full mineralization of the target compounds or as much as possible of them in mixture of compounds.

For example, in a study performed by Paul et al. (2010), the effects of photolytic and photocatalytic treatment processes on the antibacterial activity of ciprofloxacin solutions in deionized water were examined. The rates of ciprofloxacin degradation under comparable solution conditions ( $100 \mathrm{mM}$ ciprofloxacin, 0 or $0.5 \mathrm{~g} \mathrm{~L}^{-1}$ $\mathrm{TiO}_{2}, \mathrm{pH} 6,25^{\circ} \mathrm{C}$ ) follow the trend $\mathrm{UVA}-\mathrm{TiO}_{2}>\mathrm{Vis}-\mathrm{TiO}_{2}$. Release of ammonia and fluoride ions was observed and a range of organic products has been preliminarily identified with liquid chromatography-tandem mass spectrometry. During photocatalysis, the organic product analysis suggested that piperazine ring transformations generally proceed first by ring cleavage, followed by loss of the secondary amine nitrogen. However, the identified organic products all appear to retain the core quinolone structure, raising concerns about residual antibacterial potency of the treated solutions. Quantitative microbiological assays with a reference $E$. 
Table 3

Studies entailing identification of TPs and/or tentative degradation pathways and/or evaluation of their biological effects during the application of advanced oxidation processes.

\begin{tabular}{|c|c|c|c|c|c|c|}
\hline $\begin{array}{l}\text { Compound } \\
C_{0} \text {, initial concentration }\end{array}$ & Matrix & Light source & Identification of TPs & $\begin{array}{l}\text { Tentative degradation } \\
\text { pathway }\end{array}$ & $\begin{array}{l}\text { Evaluation of biological } \\
\text { effects }\end{array}$ & Reference \\
\hline \multicolumn{7}{|c|}{$\mathrm{TiO}_{2}$ photocatalytic treatment } \\
\hline $\begin{array}{l}\text { Acetaminophen } \\
C_{0}=100 \mu \mathrm{M}\end{array}$ & Bidistilled water & UV A Lamp & $r$ & $\boldsymbol{r}$ & - & Zhang et al. (2008) \\
\hline $\begin{array}{l}\text { Atenolol } \\
\text { Propranolol } \\
\text { Metoprolol } \\
C_{0}=100 \mu \mathrm{M}\end{array}$ & Milli-Q water & UV A Lamp & $r$ & $r$ & - & Yang et al. (2010a) \\
\hline $\begin{array}{l}\text { Atenolol } \\
C_{0}=10 \mathrm{mg} \mathrm{L}^{-1}\end{array}$ & $\begin{array}{l}\text { Distilled water } \\
\text { Synthetic urban } \\
\text { wastewater }\end{array}$ & Solar pilot plant & $r$ & $r$ & - & Radjenović et al. (2009a,b) \\
\hline $\begin{array}{l}\text { Mixture of } \\
\text { Amoxicillin }\left(10 \mathrm{mg} \mathrm{L}^{-1}\right) \\
\text { Carbamazepine }\left(5 \mathrm{mg} \mathrm{L}^{-1}\right) \\
\text { Diclofenac }\left(2.5 \mathrm{mg} \mathrm{L}^{-1}\right)\end{array}$ & Urban wastewater & UV A Lamp & - & - & $\begin{array}{l}\text { D. magna } \\
\text { P. subcapitata } \\
\text { L. sativum }\end{array}$ & Rizzo et al. (2009b) \\
\hline $\begin{array}{l}\text { Bezafibrate } \\
C_{0}=1 \mathrm{mg} \mathrm{L}^{-1}\end{array}$ & Bidistilled water & Solar simulator & $\boldsymbol{r}$ & $r$ & - & $\begin{array}{l}\text { Lambropoulou et al. } \\
\text { (2008) }\end{array}$ \\
\hline $\begin{array}{l}\text { Clofibric acid } \\
C_{0}=200 \mathrm{mg} \mathrm{L}^{-1}\end{array}$ & Milli-Q water & Solar simulator & $r$ & $r$ & - & Doll and Frimmel (2004) \\
\hline $\begin{array}{l}\text { Diclofenac } \\
C_{0}=5-80 \mathrm{mg} \mathrm{L}^{-1}\end{array}$ & & UV A Lamp & - & - & $\begin{array}{l}\text { D. magna } \\
\text { A. salina } \\
\text { P. subcapitata }\end{array}$ & Rizzo et al. (2009a) \\
\hline $\begin{array}{l}\text { Diclofenac } \\
C_{0}=10 \mathrm{mg} \mathrm{L}^{-1}\end{array}$ & Milli-Q water & UV A Lamp & - & - & D. magna & Achilleos et al. (2010) \\
\hline $\begin{array}{l}\text { Diclofenac } \\
C_{0}=15 \mathrm{mg} \mathrm{L}^{-1}\end{array}$ & Milli-Q water & Solar simulator & $r$ & $r$ & V. fischeri & Calza et al. (2006) \\
\hline $\begin{array}{l}\text { Erythomycin } \\
C_{0}=30 \mathrm{mg} \mathrm{L}^{-1}\end{array}$ & $\begin{array}{l}\text { Ultrapure water } \\
\text { (EASYpureRF) }\end{array}$ & UV A Lamp & - & - & Antibiotic activity & $\begin{array}{l}\text { Xekoukoulotakis et al. } \\
\text { (2010) }\end{array}$ \\
\hline $\begin{array}{l}\text { Ibuprofen } \\
C_{0}=200 \mathrm{mg} \mathrm{L}^{-1}\end{array}$ & Milli-Q water & Solar simulator & $r$ & $r$ & V. fischeri & $\begin{array}{l}\text { Méndez-Arriaga et al. } \\
\text { (2008) }\end{array}$ \\
\hline $\begin{array}{l}\text { Ofloxacin } \\
\text { Atenolol } \\
C_{0}=10 \mathrm{mg} \mathrm{L}^{-1}\end{array}$ & Milli-Q water & UV A Lamp & - & - & D. magna & Hapeshi et al. (2010) \\
\hline $\begin{array}{l}\text { Ofloxacin } \\
C_{0}=10 \mathrm{mg} \mathrm{L}^{-1}\end{array}$ & Urban wastewater & Solar simulator & - & - & D. magna & Michael et al. (2010) \\
\hline $\begin{array}{l}\text { Oxolinic acid } \\
C_{0}=20 \mathrm{mg} \mathrm{L}^{-1}\end{array}$ & $\begin{array}{l}\text { Ultrapure water } \\
\text { (Nanopure II) }\end{array}$ & UV A Lamp & $r$ & $r$ & $\begin{array}{l}\text { Antibiotic activity } \\
\text { V. fischeri }\end{array}$ & Giraldo et al. (2010) \\
\hline $\begin{array}{l}\text { Salbutamol } \\
C_{0}=15 \mathrm{mg} \mathrm{L}^{-1}\end{array}$ & Milli-Q water & Solar simulator & $r$ & $r$ & V. fischeri & Sakkas et al. (2007) \\
\hline $\begin{array}{l}\text { Sulfachlorpyridazine } \\
\text { sulfapyridine } \\
\text { Sulfisoxazole } \\
C_{0}=100 \mu \mathrm{M}\end{array}$ & Milli-Q water & UV A Lamp & $r$ & $r$ & - & Yang et al. (2010b) \\
\hline $\begin{array}{l}\text { Sulfamethoxazole } \\
C_{0}=98 \mu \mathrm{M}\end{array}$ & Deionized water & UV Lamp & $r$ & $r$ & - & Hu et al. (2007) \\
\hline $\begin{array}{l}\text { Trimethoprim } \\
C_{0}=20 \mathrm{mg} \mathrm{L}^{-1}\end{array}$ & $\begin{array}{l}\text { Demineralised water } \\
\text { Simulated seawater }\end{array}$ & Solar pilot plant & $\boldsymbol{v}_{\text {(in both matrices) }}$ & $r$ & V. fischeri & Sirtori et al. (2010) \\
\hline
\end{tabular}




\begin{tabular}{|c|c|c|c|c|c|c|}
\hline $\begin{array}{l}\text { Compound } \\
C_{0} \text {, initial concentration }\end{array}$ & Matrix & Light source & Identification of TPs & $\begin{array}{l}\text { Tentative degradation } \\
\text { pathway }\end{array}$ & $\begin{array}{l}\text { Evaluation of biological } \\
\text { effects }\end{array}$ & Reference \\
\hline \multicolumn{7}{|c|}{$U V / \mathrm{H}_{2} \mathrm{O}_{2}$ oxidation } \\
\hline $\begin{array}{l}\text { Ibuprofen } \\
\text { Diphenhydramine } \\
\text { Phenazone } \\
\text { Phenytoin } \\
C_{0}=5 \mu \mathrm{M}\end{array}$ & Deionized water & UV A Lamp & $r$ & for phenazone & - & Yuan et al. (2009) \\
\hline $\begin{array}{l}\text { Carbamazepine } \\
C_{0}=2 \times 10^{-2} \mathrm{mM}\end{array}$ & Bidistilled water & UV C Lamp & $\boldsymbol{r}$ & $\boldsymbol{r}$ & - & Vogna et al. (2004a) \\
\hline $\begin{array}{l}\text { Diclofenac } \\
C_{0}=10^{-3} \mathrm{M}\end{array}$ & Bidistilled water & UV C Lamp & $r$ & $\boldsymbol{r}$ & - & Vogna et al. (2004b) \\
\hline \multicolumn{7}{|c|}{ Sonolysis } \\
\hline Compound & Matrix & Ultrasound Frequency & $\begin{array}{l}\text { Identification of } \\
\text { byproducts }\end{array}$ & $\begin{array}{l}\text { Tentative degradation } \\
\text { pathway }\end{array}$ & $\begin{array}{l}\text { Evaluation of biological } \\
\text { effects }\end{array}$ & Reference \\
\hline$C_{0}$, initial concentration & & Power density & & & & \\
\hline $\begin{array}{l}3 \text { Mixtures of } \\
\text { Amoxicillin } \\
\text { Carbamazepine } \\
\text { Diclofenac }\end{array}$ & Urban wastewater & $\begin{array}{l}20 \mathrm{kHz} \\
100 \mathrm{~W} \mathrm{~L}^{-1}\end{array}$ & - & - & $\begin{array}{l}\text { D. magna } \\
\text { P. subcapitata } \\
\text { L. sativum }\end{array}$ & Naddeo et al. (2009) \\
\hline \multicolumn{7}{|l|}{$\begin{array}{l}\text { M1: } 10+5+2.5\left(\mathrm{mg} \mathrm{L}^{-1}\right) \\
\text { M2: } 5+2.5+2.5\left(\mathrm{~m} \mathrm{~L}^{-1}\right) \\
\text { M3: } 2.5+2.5+2.5\left(\mathrm{mg} \mathrm{L}^{-1}\right)\end{array}$} \\
\hline $\begin{array}{l}\text { Diclofenac } \\
C_{0}=2.5-80 \mathrm{mg} \mathrm{L}^{-1}\end{array}$ & Milli-Q water & $\begin{array}{l}20 \mathrm{kHz} \\
25-100 \mathrm{~W} \mathrm{~L}^{-1}\end{array}$ & - & - & $\begin{array}{l}\text { D. magna } \\
\text { A. salina }\end{array}$ & Naddeo et al. (2010) \\
\hline $\begin{array}{l}\text { Ciprofloxacin } \\
C_{0}=15 \mathrm{mg} \mathrm{L}^{-1}\end{array}$ & Deionized water & $\begin{array}{l}520 \mathrm{kHz}^{-1} \\
92 \mathrm{~mW} \mathrm{~mL}^{-1}\end{array}$ & - & - & $\begin{array}{l}\text { Antibiotic activity } \\
\text { P. subcapitata }\end{array}$ & De Bel et al. (2009) \\
\hline $\begin{array}{l}\text { Ibuprofen } \\
C_{0}=2.5-80 \mathrm{mg} \mathrm{L}^{-1}\end{array}$ & Milli-Q water & $\begin{array}{l}213 \mathrm{kHz} \\
55 \mathrm{~mW} \mathrm{~mL}^{-1}\end{array}$ & $r$ & - & - & Madhavan et al. (2010) \\
\hline \multicolumn{7}{|c|}{ Ozonation $^{\mathrm{a}}$} \\
\hline $\begin{array}{l}\text { Compound } \\
C_{0} \text {, initial concentration }\end{array}$ & Matrix & $\mathrm{pH}$ & $\begin{array}{l}\text { Identification of } \\
\text { byproducts }\end{array}$ & $\begin{array}{l}\text { Tentative degradation } \\
\text { pathway }\end{array}$ & $\begin{array}{l}\text { Evaluation of biological } \\
\text { effects }\end{array}$ & Reference \\
\hline $\begin{array}{l}\text { Bezafibrate } \\
C_{0}=0.5 \mathrm{mM}\end{array}$ & Aqueous solution & $6,7,8$ & $r$ & - & V. fischeri & Dantas et al. (2007) \\
\hline $\begin{array}{l}\text { Clofibric acid } \\
C_{0}=25-100 \mathrm{mg} \mathrm{L}^{-1}\end{array}$ & Milli-Q water & $1,3,5$ & $\boldsymbol{r}$ & $r$ & $\begin{array}{l}\text { V. fischeri } \\
\text { D. magna }\end{array}$ & Rosal et al. (2009) \\
\hline $\begin{array}{l}\text { Iomeprol } \\
C_{0}=10 \mathrm{mg} \mathrm{L}^{-1}\end{array}$ & Deionized water & 9 & $\boldsymbol{r}$ & - & - & Seitz et al. (2008) \\
\hline $\begin{array}{l}\text { Lincomycin } \\
C_{0}=0.5 \mathrm{mM}\end{array}$ & Aqueous solution & $3,7.5$ & - & - & $\begin{array}{l}\text { Antialgal activity } \\
\text { S. leopoliensis }\end{array}$ & Andreozzi et al. (2006) \\
\hline $\begin{array}{l}\text { Oxytetracycline } \\
C_{0}=100 \mathrm{mg} \mathrm{L}^{-1}\end{array}$ & Milli-Q water & $3,7,11$ & - & - & V. fischeri & Li et al. (2008) \\
\hline $\begin{array}{l}\text { Procaine penicillin G } \\
\text { Initial COD } 600 \mathrm{mg} \mathrm{L}^{-1}\end{array}$ & Formulation effluent & 7,12 & - & - & $\begin{array}{l}\text { Activated sludge } \\
\text { inhibition } \\
\text { D. magna }\end{array}$ & $\begin{array}{l}\text { Arslan-Alaton and } \\
\text { Caglayan (2006) }\end{array}$ \\
\hline $\begin{array}{l}\text { Paracetamol } \\
C_{0}=5.3 \times 10^{-3} \\
\text { mol dm }{ }^{-3} \mathrm{at} \mathrm{pH} 2 \\
C_{0}=4.9 \times 10^{-3} \mathrm{~mol} \mathrm{dm}^{-3} \\
\text { at pH } 7\end{array}$ & Aqueous solution & 2,7 & レ & $\boldsymbol{r}$ & - & Andreozzi et al. (2003) \\
\hline $\begin{array}{l}\text { Sulfamethoxazole } \\
C_{0}=200 \mathrm{mg} \mathrm{L}^{-1}\end{array}$ & Aqueous solution & $3,7,11$ & - & - & V. fischeri & Dantas et al. (2008) \\
\hline
\end{tabular}




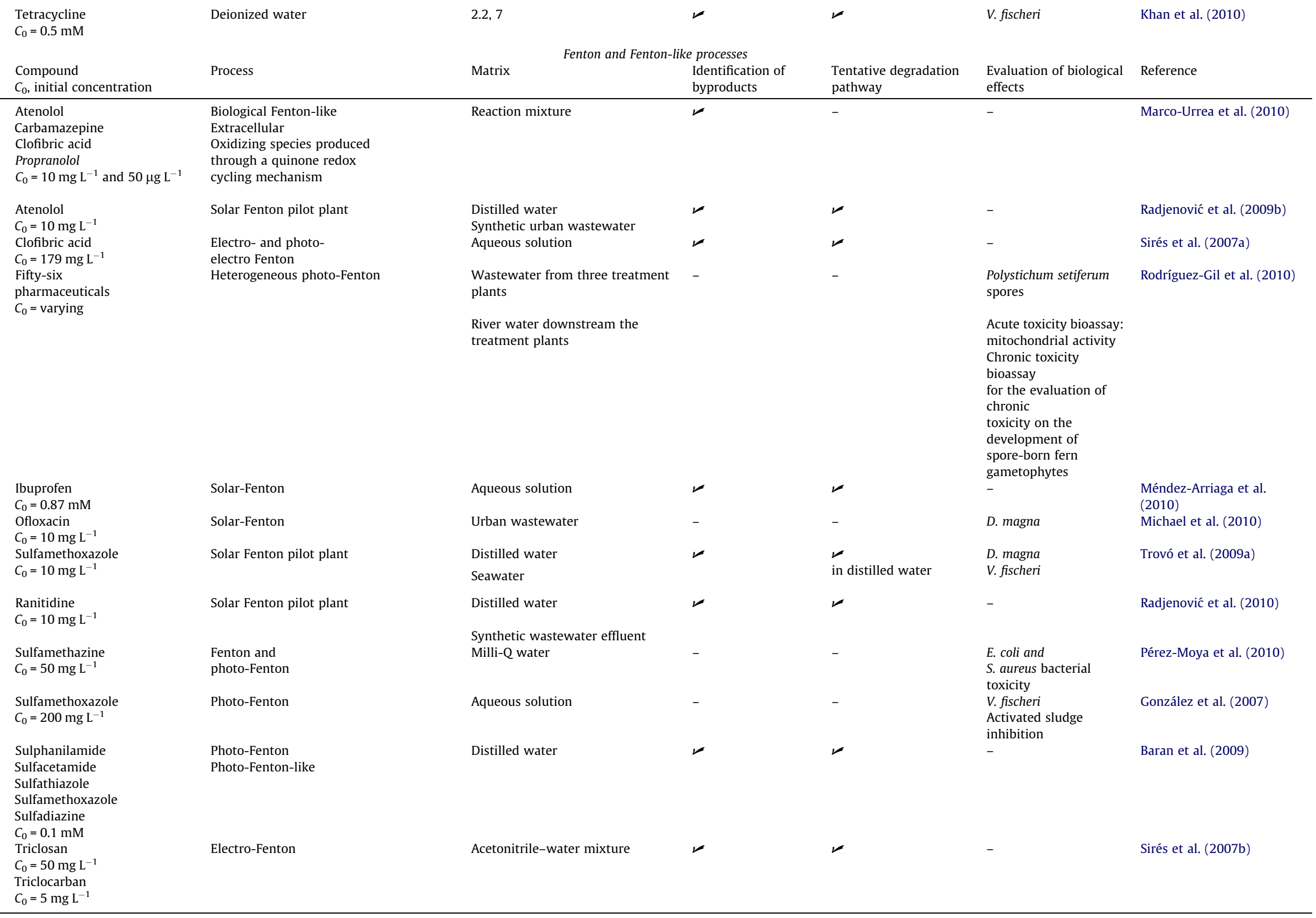

${ }^{\mathrm{a}} \mathrm{pH}$ is provided so as to differentiate ozonation from ozonation considered as an advanced oxidation process (for which $\mathrm{pH}>7$ ). 
coli strain indicated that the antimicrobial potency of ciprofloxacin solutions track closely with the undegraded ciprofloxacin concentration during photocatalytic reactions. Quantitative analysis showed that for each mole of ciprofloxacin degraded, the antibacterial potency of irradiated solutions decreased by approximately one 'mole' of activity relative to that of the untreated ciprofloxacin solution. This indicated that the ciprofloxacin photocatalytic TPs retain negligible antibacterial activity compared to the parent compound.

Giraldo et al. (2010), worked with a photocatalytic system using titania suspension to evaluate the degradation of $20 \mathrm{mg} \mathrm{L}^{-1}$ of antibiotic oxolinic acid. Under optimal conditions the evolution of the substrate, chemical oxygen demand, dissolved organic carbon, toxicity and antimicrobial activity on Escherichia coli cultures were evaluated. The results indicated that, under optimal conditions, after $30 \mathrm{~min}$, the $\mathrm{TiO}_{2}$ photocatalytic system was able to eliminate both the substrate and the antimicrobial activity, and to reduce the toxicity of the solution by $60 \%$. However, at the same time, ca. $53 \%$ of both initial DOC and COD remained in solution. Thus, the photocatalytical system was able to transform the target compound into more oxidized byproducts without antimicrobial activity and with a low toxicity by measuring the $\mathrm{EC}_{50}$ on $\mathrm{V}$. fischeri.

Solar $\mathrm{TiO}_{2}$ photocatalysis of trimethoprim in different water matrices (demineralised and simulated seawater) has been studied by Sirtori et al. (2010). During the process, the compound was completely eliminated in both water matrices at a similar rate. However, the mineralization rate was appreciably reduced in seawater, which could be explained by the presence of inorganic species acting as hydroxyl radical scavengers, and directly affecting photocatalytic efficiency. Identification of intermediates showed differences between photolysis and photocatalysis but hydroxylation, demethylation and cleavage of the original drug molecule were observed in both. A small increase in the inhibition of $V$. fischeri was observed indicating that the TPs were moderately toxic for the organism tested.

The degradation of an aqueous solution of clofibric acid was investigated by Rosal et al. (2009), during catalytic and non-catalytic ozonation. The catalyst, $\mathrm{TiO}_{2}$, enhanced the production of hydroxyl radicals from ozone and raised the fraction or clofibric acid degraded by hydroxyl radicals. The rate constant for the reaction of clofibric acid and hydroxyl radicals was not affected by the presence of the catalyst. The toxicity of the oxidation products obtained during the reaction was assessed by means of $V$. fischeri and $D$. magna tests in order to evaluate the potential formation of toxic TPs. The results showed that the ozonation was enhanced by the presence of $\mathrm{TiO}_{2}$, the clofibric acid being removed completely after $15 \mathrm{~min}$ at $\mathrm{pH} 5$. The evolution of dissolved organic carbon, specific ultraviolet absorption at $254 \mathrm{~nm}$ and the concentration of carboxylic acids monitored the degradation process. The formation of 4-chlorophenol, hydroquinone, 4-chlorocatechol, 2-hydroxyisobutyric acid and three non-aromatic compounds identified as a product of the ringopening reaction was assessed by exact mass measurements performed by liquid chromatography coupled to time-of-flight mass spectrometry. The bioassays showed a significant increase in toxicity during the initial stages of ozonation following a toxicity pattern closely related to the formation of ring-opening byproducts, decreasing though in the end.

Trovó et al. (2009b) worked on the photocatalytic degradation of sulfamethoxazole by solar photo-Fenton at pilot plant scale in distilled water and in seawater. Degradation and mineralization of sulfamethoxazole were strongly hindered in seawater compared to distilled water. The influence of $\mathrm{H}_{2} \mathrm{O}_{2}$ and iron concentration on the efficiency of the photocatalytic process was evaluated. An increase in $\mathrm{H}_{2} \mathrm{O}_{2}$ concentration up to $120 \mathrm{mg} \mathrm{L}^{-1}$ during photoFenton in distilled water decreased sulfamethoxazole solution toxicity from $85 \%$ to $20 \%$, according to results of $D$. magna bioassays.
The same behavior was not observed after photo-Fenton treatment in seawater. Despite $45 \%$ mineralization in seawater, toxicity increased from $16 \%$ to $86 \%$ as shown by $V$. fischeri bioassays, which suggests that the intermediates generated in seawater are different from those in distilled water.

The aforementioned studies reveal for once again the need for more uniform experimental conditions, simulating more realistic conditions on the one hand and standardized ones in parallel to gain insight into the significance of real world conditions so as to be able to extract meaningful and useful conclusions on the formation of TPs during photo-driven and advanced oxidation processes and their biological potency.

\section{Conclusions on gaps and needs}

Since drugs are considered environmental pollutants, it is not only important to investigate what these compounds degrade into after their release in environmental media and the persistence of products relative to the initial compound, but also whether the degradation products retain the activity of the parent molecule to elicit a toxicological effect on non-target organisms in environmental systems both aquatic and terrestrial. Most studies concluded that it is unlikely that non-target organisms would be exposed to concentrations causing acute toxicity, but often at these concentrations, chronic, sublethal effects were found to exist. According to Muñoz et al. (2009), who performed a Life Cycle Analysis of urban wastewater reuse with ozonation as tertiary treatment, the first aspect they highlighted is the need to include wastewater pollutants in such studies along with their toxicity assessments. Global parameters such TOC, COD, etc. can no longer contribute to decisions on reuse schemes because the residual effluent organic content of the effluent may contain mixtures of parent compounds, their metabolites and transformation products whose biological potency needs a careful assessment and consideration. This fact is also addressed in the paper by Fatta-Kassinos et al. (in press) who discuss the fact that although the wastewater reuse practice is accompanied by a number of benefits relating to the enhancement of water balances and soil nutrition by the nutrients existing in the treated effluents, a number of unanswered questions are still related to this practice in relation to xenobiotics present in the treated effluents.

Many difficulties have to be overcome for the evaluation of the ecotoxicological potency of the TPs which are related to the formation of a large number of unknown compounds that complicate their identification in environmental matrices, the different physicochemical properties of the TPs that make their determination difficult with only one extraction and/or analytical procedure, and the absence, in most cases, of analytical standards to confirm their chemical structure. However, since knowing the potency of the treated flow is of great importance, toxicity assessment of TPs should be included in the various studies even if implemented without elucidation of the structures of transformation products. This will give useful insight on whether a treatment or natural process can be or not be useful on a practical level under real conditions.

It is now well accepted and scientifically documented that disappearance of the original form of a pharmaceutical compound may be achieved fast by a variety of processes. Photo-Fenton processes for example are able to achieve preliminary elimination of pharmaceuticals in less than 15 min in many cases. However, TPs are formed which can often be less biodegradable, more toxic and inhibitory than the parent compound. Most of the processes described in this paper are photo-driven. Therefore there is an apparent need to direct efforts to understand these photolytic transformations and oxidative/reductive reactions that take place in such processes and what is even more important is to achieve elucidation of the productśs structures that are ecotoxicological rel- 
evant determining also the time needed for their formation under specific conditions. The potentially additive, antagonistic and synergetic effects of these compounds when present in mixtures with parent compounds and other naturally occurring compounds and chemical elements need to be also investigated both for acute and more importantly chronic effects focusing not only on toxicity but also on mutagenicity and other relevant potential effects.

The number of studies dedicated to pharmaceuticals and solar irradiation in the natural aquatic environment as discussed by Boreen et al. already in 2003 and those focusing on the application of AOPs (Klavarioti et al., 2009) for their removal, follows a remarkably increasing trend during the recent years. However, the majority of the studies are focused mainly on the investigation of the operational parameters and kinetics. It is only the minority of them that include work on the identification of the TPs formed and/or on the assessment of the biological potency of the treated solution/ effluent produced.

Concerning the various discrepancies and differences in the experimental configurations applied for the photo-driven processes but also the various advanced oxidation processes, available in the literature, the most important ones that prevent the scientific community from researching credible and solid conclusions have been presented herein. Standardized tests are perhaps needed at least for photolysis and photocatalysis for matrices like water and urban wastewater. An example is the guidelines existing for photolysis and surface water, i.e. OECD 316 (phototransformation of chemicals in water-direct photolysis), which are not applied though by the scientific community always. This could lead to the implementation of standardized testing conditions and consequently the literature would then allow for concrete comparison and understanding of the various relevant results.

One of the most important questions is the initial concentration of the various compounds studied under photolysis or advanced oxidation processes. Many research groups point out the fact that using higher than the relevant concentrations is for the moment required due to the analytical capabilities currently available which is of course valid but still hindering the understanding of the actual situation in nature. Results from kinetics studies are still not able to provide answers towards this direction. Moreover, the variety of the matrices studied cannot also facilitate understanding. For example, Trovó et al. (2009a) proved that the TPs of sulfamethoxazole formed in distilled water and seawater were different and consequently their behavior in the ecotoxicological study different as well. Some of the studies indicate a lesser or higher toxicity of the products formed during the study of the various individual compounds examined and thus a global conclusion cannot be drawn. What is more, differences or similarities between laboratory scale, pilot and industrial scale have not yet been credibly established.

Photodegraded products have not yet been identified in the aquatic environment due to the lack of analytical standards and the complex matrix of organic molecules in the environmental samples. It consequently still remains unclear whether the photoproducts determined during laboratory scale photolytic or AOPs applications especially when using ultrapure water matrix and single-compound solutions are also formed under real conditions in the environment.

Concerning the ecotoxicological effects, as already known for the parent compounds, there is still a lot to be done since even though substantial information has started to be compiled, organisms, conditions, assays, concentrations, etc. vary and often-contradictory results are obtained from the biological assays. It is also not determined yet which organisms and which endpoints are relevant for the pharmaceuticals biological potency testing. This stands of course true for the phototransformed compounds as well.
The possible interactions between parent compounds, transformed products and environmental conditions are still unknown. The absence of knowledge with regard to experimental data is also associated with the great difficulty to develop models for the prediction of the fate of such pollutants. As a consequence, researchers, scientists and also policy makers have still major difficulties in presenting possible existing and future challenges with supported data.

\section{Acknowledgements}

This work has been prepared in the framework of the PENEK/ 0609/24 research project "Development of novel methods for the toxicity assessment of the multi-component chemical mixtures to humans and the ecosystem (TOMIXX)", implemented within the framework of the program for research, technological development and innovation "DESMH 2009-2010" and stimulated by the project UPGRADING/DURABLE/0308/07, "Fate, Effect and Removal Potential of Xenobiotics present in Aqueous Matrices (IX-Aqua)" through "DESMH 2008". These projects are co-funded by the Republic of Cyprus and the European regional development fund through the Research Promotion Foundation of Cyprus.

\section{References}

Achilleos, A., Hapeshi, E., Xekoukoulotakis, N.P., Mantzavinos, D., Fatta-Kassinos, D., 2010. Factors affecting diclofenac decomposition in water by UV-A/TiO photocatalysis. Chem. Eng. J. 161, 53-59.

Agüera, A., Pérez Estrada, L.A., Ferrer, I., Thurman, E.M., Malato, S., Fernández-Alba, A.R., 2005. Application of time-of-flight mass spectrometry to the analysis of phototransformation products of diclofenac in water under natural sunlight. J. Mass Spectrom. 40, 908-915.

Albini, A., Fasani, E., 1998. Photochemistry of drugs: an overview and practical problems. In: Albini, A., Fasani, E. (Eds.), Drugs-Photochemistry and Photostability. The Royal Society of Chemistry, Cambridge, p. 2.

Andreozzi, R., Caprio, V., Marotta, R., Vogna, D., 2003. Paracetamol oxidation from aqueous solutions by means of ozonation and $\mathrm{H}_{2} \mathrm{O}_{2} / \mathrm{UV}$ system. Water Res. 37, 993-1004.

Andreozzi, R., Canterino, M., Giudice, R.L., Marotta, R., Pinto, G., Pollio, A., 2006. Lincomycin solar photodegradation, algal toxicity and removal from wastewaters by means of ozonation. Water Res. 40, 630-638.

Arslan-Alaton, I., Caglayan, A.E., 2006. Toxicity and biodegradability assessment of raw and ozonated procaine penicillin $G$ formulation effluent. Ecotoxicol. Environ. Saf. 63, 131-140.

Baran, W., Adamek, E., Sobczak, A., Makowski, A., 2009. Photocatalytic degradation of sulfa drugs with $\mathrm{TiO}_{2}$, Fe salts and $\mathrm{TiO}_{2} / \mathrm{FeCl}_{3}$ in aquatic environment kinetics and degradation pathway. Appl. Catal. B 90, 516-525.

Bartels, P., von Tümpling Jr., W., 2008. The environmental fate of the antiviral drug oseltamivir carboxylate in different waters. Sci. Total Environ. 405, 215-225.

Boreen, A.L., Arnold, W.A., McNeill, K., 2003. Photodegradation of pharmaceuticals in the aquatic environment: a review. Aquat. Sci. 65, 320-341.

Brezonik, P.L., Fulkerson-Brekken, J., 1998. Nitrate-induced photolysis in natural waters: controls on concentrations of hydroxyl radical photo-intermediates by natural scavenging agents. Environ. Sci. Technol. 32, 3004-3010.

Brigante, M., DellaGreca, M., Previtera, L., Rubino, M., Temussi, F., 2005. Degradation of hydrochlorothiazide in water. Environ. Chem. Lett. 2, 195-198.

Buxton, B.V., Greenstock, C.L., Helman, W.P., Ross, A.B., 1988. Critical review of rate constants for reactions of hydrated electrons, hydrogen atoms, and hydroxyl radicals in aqueous solution. J. Phys. Chem. Ref. Data 17, 513-886.

Calza, P., Sakkas, V.A., Medana, C., Baiocchi, C., Dimou, A., Pelizzetti, E., Albanis, T. 2006. Photocatalytic degradation study of diclofenac over aqueous $\mathrm{TiO}_{2}$ suspensions. Appl. Catal. B 67, 197-205.

Cermola, M., DellaGreca, M., Iesce, M.R., Previtera, L., Rubino, M., Temussi, F., Brigante, M., 2005. Phototransformation of fibrate drugs in aqueous media. Environ. Chem. Lett. 3, 43-47.

Dantas, R.F., Canterino, M., Marotta, R., Sans, C., Esplugas, S., Andreozzi, R., 2007. Bezafibrate removal by means of ozonation: primary intermediates, kinetics, and toxicity assessment. Water Res. 41, 525-2532.

Dantas, R.F., Contreras, S., Sans, C., Esplugas, S., 2008. Sulfamethoxazole abatement by means of ozonation. J. Hazard. Mater. 150, 790-794.

Dantas, R., Rossiter, O., Kardec Ribeiro Teixeira, A., Simões, A.S.M., Lins da Silva, V., 2010. Direct UV photolysis of propranolol and metronidazole in aqueous solution. Chem. Eng. J. 158, 143-147.

De Bel, E., Dewulf, J., De Witte, B., Van Langenhove, H., Janssen, C., 2009. Influence of $\mathrm{pH}$ on the sonolysis of ciprofloxacin: biodegradability, ecotoxicity and antibiotic activity of its degradation products. Chemosphere 77, 291-295. 
DellaGreca, M., Brigante, M., Isidori, M., Nardelli, A., Previtera, L., Rubino, M., Temussi, F., 2004. Phototransformation and ecotoxicity of the drug NaproxenNa. Environ. Chem. Lett. 1, 237-241.

Doll, T.E., Frimmel, F.H., 2004. Kinetic study of photocatalytic degradation of carbamazepine, clofibric acid, iomeprol and iopromide assisted by different $\mathrm{TiO}_{2}$ materials - determination of intermediates and reaction pathways. Water Res. 38, 955-964.

Fatta-Kassinos, D., Kalavrouziotis, I.K., Koukoulakis, P.H., Vasquez, M.I., in press. The risks associated with wastewater reuse and xenobiotics in the agroecological environment. Sci. Total Environ.

Giraldo, A.L., Peñuela, G.A., Torres-Palma, R.A., Pino, N.J., Palominos, R.A., Mansilla, H.D., 2010. Degradation of the antibiotic oxolinic acid by photocatalysis with $\mathrm{TiO}_{2}$ in suspension. Water Res. 44, 5158-5167.

Gómez, M.J., Sirtori, C., Mezcua, M., Fernández-Alba, A.R., Agüera, A., 2008. Photodegradation study of three dipyrone metabolites in various water systems: identification and toxicity of their photodegradation products. Water Res. 42, 2698-2706.

González, O., Sans, C., Esplugas, S., 2007. Sulfamethoxazole abatement by photoFenton: toxicity, inhibition and biodegradability assessment of intermediates. J. Hazard. Mater. 146, 459-464.

Hapeshi, E., Achilleos, A., Vasquez, M.I., Michael, C., Xekoukoulotakis, N.P., Mantzavinos, D., Kassinos, D., 2010. Drugs degrading photocatalytically: kinetics and mechanisms of ofloxacin and atenolol removal on titania suspensions. Water Res. 44, 1737-1746.

Heberer, T., 2002. Occurrence, fate and removal of pharmaceutical residues in the aquatic environment: a review of recent research data. Toxicol. Lett. 131, 5-17.

Hu, L., Flanders, P.M., Miller, P.L., Strathmann, T.J., 2007. Oxidation of sulfamethoxazole and related antimicrobial agents by $\mathrm{TiO}_{2}$ photocatalysis. Water Res. 41, 2612-2626.

Isidori, M., Nardelli, A., Parrella, A., Pascarella, L., Previtera, L., 2006. A multispecies study to assess the toxic and genotoxic effect of pharmaceuticals: furosemide and its photoproduct. Chemosphere 63, 785-793.

Jiao, S., Zheng, S., Yin, D., Wang, L., Chen, L., 2008. Aqueous photolysis of tetracycline and toxicity of photolytic products to luminescent bacteria. Chemosphere 73, 377-382.

Khan, M.H., Bae, H., Jung, J.Y., 2010. Tetracycline degradation by ozonation in the aqueous phase: proposed degradation intermediates and pathway. J. Hazard. Mater. 181, 659-665.

Klavarioti, M., Mantzavinos, D., Kassinos, D., 2009. Removal of residual pharmaceuticals from aqueous systems by advanced oxidation processes. Environ. Int. 35, 402-417.

Kosjek, T., Heath, E., 2008. Applications of mass spectrometry to identifying pharmaceutical transformation products in water treatment. Trends Anal. Chem. 27, 807-820.

Kümmerer, K. (Ed.), 2008. Pharmaceuticals in the environment, 3rd ed.. Sources, Fate, Effects and Risks Springer-Verlag, Berlin Heidelberg.

Kümmerer, K., 2009. The presence of pharmaceuticals in the environment due to human use - present knowledge and future challenges. J. Environ. Manage. 90, 2354-2366.

Kusari, S., Prabhakaran, D., Lamshöft, M., Spiteller, M., 2009. In vitro residual antibacterial activity of difloxacin, sarafloxacin and their photoproducts after photolysis in water. Environ. Pollut. 157, 2722-2730.

Lam, M.W., Mabury, S.A., 2005. Photodegradation of the pharmaceuticals atorvastatin, carbamazepine, levofloxacin, and sulfamethoxazole in natural waters. Aquat. Sci. 67, 177-188.

Lambropoulou, D.A., Hernando, M.D., Konstantinou, I.K., Thurman, E.M., Ferrer, I., Albanis, T.A., Fernández-Alba, A.R., 2008. Identification of photocatalytic degradation products of bezafibrate in $\mathrm{TiO}_{2}$ aqueous suspensions by liquid and gas chromatography. J. Chromatogr. A 1183, 38-48.

Li, K., Yediler, A., Yang, M., Schulte-Hostede, S., Wong, M.H., 2008. Ozonation of oxytetracycline and toxicological assessment of its oxidation byproducts. Chemosphere 72, 473-478.

Liu, Q.T., Williams, H., 2007. Kinetics and degradation products for direct photolysis of ß-blockers in water. Environ. Sci. Technol. 41, 803-810.

Liu, Q.T., Cumming, R.I., Sharpe, A.D., 2009. Photo-induced environmental depletion processes of b-blockers in river waters. Photochem. Photobiol. Sci. 8, 741-888.

Madhavan, J., Grieser, F., Ashokkumar, M., 2010. Combined advanced oxidation processes for the synergistic degradation of ibuprofen in aqueous environments. J. Hazard. Mater. 178, 202-208.

Maquille, A., Habib Jiwanb, J.L., 2009. LC-MS characterization of metoclopramide photolysis products. J. Photochem. Photobiol. A Chem. 205, 197-202.

Maquille, A., Salembier, S., Hérent, M.F., Habib Jiwan, J.L., 2010. Photodegradation of flupentixol in aqueous solution under irradiation at $254 \mathrm{~nm}$ : identification of the photoproducts generated. J. Photochem. Photobiol. A Chem. 214, 224-229.

Marco-Urrea, E., Radjenović, J., Caminal, G., Petrović, M., Vicent, T., Barceló, D., 2010. Oxidation of atenolol, propranolol, carbamazepine and clofibric acid by a biological Fenton-like system mediated by the white-rot fungus Trametes versicolor. Water Res. 44, 521-532.

Matamoros, V., Duhec, A., Albaigés, J., Bayona, J.M., 2009. Photodegradation of carbamazepine, ibuprofen, ketoprofen and $17 \alpha$-ethinylestradiol in fresh and seawater. Water Air Soil Pollut. 196, 161-168.

Méndez-Arriaga, F., Esplugas, S., Giménez, J., 2008. Photocatalytic degradation of non-steroidal anti-inflammatory drugs with $\mathrm{TiO}_{2}$ and simulated solar irradiation. Water Res. 42, 585-594.

Méndez-Arriaga, F., Esplugas, S., Giménez, J., 2010. Degradation of the emerging contaminant ibuprofen in water by photo-Fenton. Water Res. 44, 589-595.
Miao, X.S., Metcalfe, C.D., 2003. Determination of carbamazepine and its metabolites in aqueous samples using liquid chromatography-electrospray tandem mass spectrometry. Anal. Chem. 75, 3731-3738.

Michael, I., Hapeshi, E., Michael, C., Fatta-Kassinos, D., 2010. Solar Fenton and solar $\mathrm{TiO}_{2}$ catalytic treatment of ofloxacin in secondary treated effluents: evaluation of operational and kinetic parameters. Water Res. 44, 5450-5462.

Moore, D.E., Roberts-Thomson, S., Zhen, D., Duke, C.C., 1990. Photochem. Photobiol. $52,685-690$

Muñoz, I., Rodríguez, A., Rosal, R., Fernández-Alba, A.R., 2009. Life Cycle Assessment of urban wastewater reuse with ozonation as tertiary treatment: a focus on toxicity-related impacts. Sci. Total Environ. 407, 1245-1256.

Naddeo, V., Meriç, S., Kassinos, D., Belgiorno, V., Guida, M., 2009. Fate of pharmaceuticals in contaminated urban wastewater effluent under ultrasonic irradiation. Water Res. 43, 4019-4027.

Naddeo, V., Belgiorno, V., Kassinos, D., Mantzavinos, D., Meric, S., 2010. Ultrasonic degradation, mineralization and detoxification of diclofenac in water: optimization of operating parameters. Ultrason. Sonochem. 17, 179-185.

Paul, T., Dodd, M.C., Strathmann, T.J., 2010. Photolytic and photocatalytic decomposition of aqueous ciprofloxacin: transformation products and residual antibacterial activity. Water Res. 44, 3121-3132.

Pérez-Moya, M., Graells, M., Castells, G., Amigó, J., Ortega, E., Buhigas, G., Pérez, L.M. Mansilla, H.D., 2010. Characterization of the degradation performance of the sulfamethazine antibiotic by photo-Fenton process. Water Res. 44, 2533-2540.

Peuravuori, J., Pihlaja, K., 2009. Phototransformations of selected pharmaceuticals under low-energy UVA-Vis and powerful UVB-UVA irradiations in aqueous solutions - the role of natural dissolved organic chromophoric material. Anal. Bioanal. Chem. 394, 1621-1636.

Piram, A., Salvador, A., Verne, C., Herbreteau, B., Faure, R., 2008. Photolysis of $\beta$ blockers in environmental waters. Chem. 73, 1265-1271.

Prabhakaran, D., Sukul, P., Lamshöft, M., Maheswari, M.A., Zühlke, S., Spiteller, M. 2009. Photolysis of difloxacin and sarafloxacin in aqueous systems. Chemosphere 77, 739-746.

Quintana, J.B., Weiss, S., Reemtsma, T., 2005. Pathways and metabolites of microbia degradation of selected acidic pharmaceutical and their occurrence in municipal wastewater treated by a membrane bioreactor. Water Res. 39 2654-2664.

Radjenović, J., Petrović, M., Barceló, D., 2009a. Complementary mass spectrometry and bioassays for evaluating pharmaceutical-transformation products in treatment of drinking water and wastewater. Trends Anal. Chem. 28, 562-580.

Radjenović, J., Sirtori, C. Petrović, M., Barceló, D., Malato, S., 2009b. Solar photocatalytic degradation of persistent pharmaceuticals at pilot-scale: kinetics and characterization of major intermediate products. Appl. Catal. B 89, 255-264.

Radjenović, J., Sirtori, C., Petrović, M., Barceló, D., Malato, S., 2010. Characterization of intermediate products of solar photocatalytic degradation of ranitidine at pilot-scale. Chemosphere 79, 368-376.

Rivas, J., Gimeno, O., Borralho, T., Carbajo, M., 2010. UV-C photolysis of endocrine disruptors. The influence of inorganic peroxides. J. Hazard. Mater. 174, 393-397.

Rizzo, L., Meric, S., Kassinos, D., Guida, M., Russo, F., Belgiorno, V., 2009a Degradation of diclofenac by $\mathrm{TiO}_{2}$ photocatalysis: UV absorbance kinetics and process evaluation through a set of toxicity bioassays. Water Res. 43, 979988.

Rizzo, L., Meric, S., Guida, M., Kassinos, D., Belgiorno, V., 2009b. Heterogenous photocatalytic degradation kinetics and detoxification of an urban wastewate treatment plant effluent contaminated with pharmaceuticals. Water Res. 43 , 4070-4078.

Rodríguez-Gil, J.L., Catalá, M., González Alonso, S., Romo Maroto, R., Valcárcel, Y. Segura, Y., Molina, R., Melero, J.A. Martínez, F. 2010. Heterogeneous photoFenton treatment for the reduction of pharmaceutical contamination in Madrid rivers and ecotoxicological evaluation by a miniaturized fern spores bioassay. Chemosphere 80, 381-388.

Rosal, R., Gonzalo, M.S., Boltes, K., Letón, P., Vaquero, J.J., García-Calvo, E., 2009 Identification of intermediates and assessment of ecotoxicity in the oxidation products generated during the ozonation of clofibric acid. J. Hazard. Mater. 172, $1061-1068$

Russi, H., Kotzias, D., Korte, F., 1982. Photoinduced hydroxylation reactions of organic chemicals in natural waters - nitrates as potential sources for $\mathrm{OH}-$ radicals. Chemosphere 11, 1041-1048.

Sakkas, V.A., Calza, P., Medana, C., Villioti, A.E., Baiocchi, C., Pelizzetti, E., Albanis, T., 2007. Heterogeneous photocatalytic degradation of the pharmaceutical agent salbutamol in aqueous titanium dioxide suspensions. Appl. Catal. B 77, 135144.

Sanz, A., Moreno, I., Castresana, C., 1998. Plant Cell 10, 1523-1537.

Schmitt-Jansen, M., Bartels, P., Adler, N., Altenburger, R., 2007. Phytotoxicity assessment of diclofenac and its phototransformation products. Anal. Bioanal. Chem. 387, 1389-1396.

Schulze, T., Weiss, S., Schymanski, E., Carsten von der Ohe, P., Schmitt-Jansen, M., Altenburger, R., Streck, G., Brack, W., 2010. Identification of a phytotoxic photo-transformation product of diclofenac using effectdirected analysis. Environ. Pollut. 158, 1461-1466.

Seitz, W., Jiang, J.Q., Schulz, W., Weber, W.H., Maier, D., Maier, M., 2008. Formation of oxidation by-products of the iodinated X-ray contrast medium iomeprol during ozonation. Chemosphere 70, 1238-1246.

Sirés, I., Arias, C., Cabot, P.L., Cenetllas, F., Garrido, J.A., Rodríguez, R.M., Brillas, E., 2007a. Degradation of clofibric acid in acidic aqueous medium by electroFenton and photoelectron-Fenton. Chemosphere 66, 1660-1669. 
Sirés, I., Oturan, N., Oturan, M.A., Rodríguez, R.M., Garrido, J.A., Brillas, E., 2007b. Electro-Fenton degradation of antimicrobials triclosan and triclocarban. Electrochim. Acta 52, 5493-5503.

Sirtori, C., Agüera, A., Gernjak, W., Malato, S., 2010. Effect of water-matrix composition on Trimethoprim solar photodegradation kinetics and pathways. Water Res. 44, 2735-2744.

Sunderland, J., Tobin, C.M., Hedges, A.J., MacGowan, A.P., White, L.O., 2001. Antimicrobial activity of fluoroquinolone photodegradation products determined by parallel-line bioassay and high performance liquid chromatography. J. Antimicrob. Chemother. 47, 271-275.

Trovó, A.G., Nogueira, R.F.P., Agüera, A., Sirtori, C., Fernández-Alba, A.R., 2009a Photodegradation of sulfamethoxazole in various aqueous media: persistence, toxicity, photoproducts assessment,. Chemosphere 77, 1292-1298.

Trovó, A.G., Nogueira, R.F.P., Agüera, A., Fernandez-Alba, A.R., Sirtori, C., Malato, S. 2009b. Degradation of sulfamethoxazole in water by solar photo-Fenton. Chemical and toxicological evaluation. Water Res. 43, 3922-3931.

Vasconcelos, T.G., Henriques, D.M., König, A., Martins, A.F., Kümmerer, K., 2009 Photo-degradation of the antimicrobial ciprofloxacin at high pH: identification and biodegradability assessment of the primary by-products. Chemosphere 76 , 487-493.

Vione, D., Feitosa-Felizzola, J., Minero, C., Chiron, S., 2009. Phototransformation of selected human-used macrolides in surface water: kinetics, model predictions and degradation pathways. Water Res. 43, 1959-1967.

Vogna, D., Marotta, R., Andreozzi, R., Napolitano, A., d'Ischia, M., 2004a. Kinetic and chemical assessment of the $\mathrm{UV} / \mathrm{H}_{2} \mathrm{O}_{2}$ treatment of antiepileptic drug carbamazepine. Chemosphere 54, 497-505.
Vogna, D., Marotta, R., Napolitano, A., Andreozzi, R., d'Ischia, M., 2004b. Advanced oxidation of the pharmaceutical drug diclofenac with $U V / \mathrm{H}_{2} \mathrm{O}_{2}$ and ozone. Water Res. 38, 414-422.

Werner, J.J., McNeill, K., Arnold, W.A., 2005. Environmental photodegradation of mefenamic acid. Chemosphere 58, 1339-1346.

Xekoukoulotakis, N.P., Xinidis, N., Chroni, M., Mantzavinos, D., Venieri, D., Hapeshi, E., Fatta-Kassinos, D., 2010. UV-A/TiO 2 photocatalytic decomposition of erythromycin in water: factors affecting mineralization and antibiotic activity. Catal. Today 151, 29-33.

Yamamoto, H., Nakamura, Y., Moriguchi, S., Nakamura, Y., Honda, Y., Tamura, I., Hirata, Y., Hayashi, A., Sekizawa, J., 2009. Persistence and partitioning of eight selected pharmaceuticals in the aquatic environment: laboratory photolysis, biodegradation, and sorption experiments. Water Res. 43, 351-362.

Yang, H., An, T., Li, G., Song, W., Cooper, W.J., Luo, H., Guo, X., 2010a. Photocatalytic degradation kinetics and mechanism of environmental pharmaceuticals in aqueous suspension of $\mathrm{TiO}_{2}$ : a case of ß-blockers. J. Hazard. Mater. 179, 834-839.

Yang, H., Li, G., An, T., Gao, Y., Fu, J., 2010b. Photocatalytic degradation kinetics and mechanism of environmental pharmaceuticals in aqueous suspension of $\mathrm{TiO}_{2}$ : a case of sulfa drugs. Catal. Today 153, 200-207.

Yuan, F., Hu, C., Hu, X., Qu, J., Yang, M., 2009. Degradation of selected pharmaceuticals in aqueous solution with $\mathrm{UV}$ and $\mathrm{UV} / \mathrm{H}_{2} \mathrm{O}_{2}$. Water Res. 43, 1766-1774.

Zhang, X., Wu, F., Wu, X., Chen, P., Deng, N., 2008. Photodegradation of acetaminophen in $\mathrm{TiO}_{2}$ suspended solution. J. Hazard. Mater. 157, 300-307.

Zwiener, C., Seeger, G., Glauner, T., Frimmel, F.H., 2002. Metabolites from the biodegradation of pharmaceutical residues of ibuprofen in biofilm reactors and batch experiments. Anal. Bioanal. Chem. 372, 569-575. 